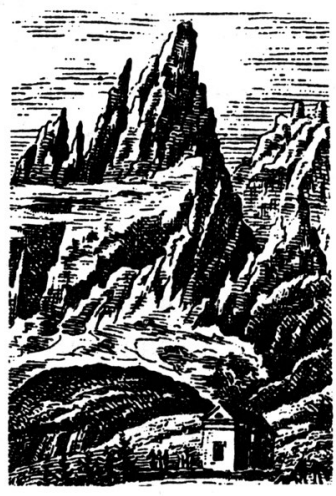

Ewa Kolbuszewska

ORCID: 0000-0001-8703-1042

Uniwersytet Wroctawski

ewa.kolbuszewska@uwr.edu.pl

https://doi.org/10.19195/2084-4107.15.13

\title{
Obraz przewodnika górskiego w literaturze romantycznej. Część I
}

Słowa-klucze: góry, turystyka, przewodnik, literatura XIX wieku

Keywords: mountains, tourism, guide, literature of the nineteenth century

\section{The image of the mountain guide in romantic literature. Part I}

\section{Summary}

The intensive development of tourism in the 19th century significantly contributed to the emergence of the guide's profession. In earlier centuries, this feat was practiced by random people, often unqualified, but with time they became indispensable companions and patrons of tourists. Special qualities were required from mountain guides who, when introducing people to the mountains, had to show special qualities: responsibility, good knowledge of the topography of a given area, care, specific knowledge, as well as good physical condition. The job was professionalized the earliest in the Alps, but the process took place more or less at the same time in other European mountains, for example in the Karkonosze Mountains. It was much more difficult to hire an experienced guide in the Carpathians, where the leadership developed much later. Travel literature of the nineteenth century brought numerous accounts describing the relationship between the guide and the tourist as 
well as providing numerous realistic descriptions of the first to "hike in the mountains". Due to the factual nature of this travel literature (diaries, memoirs, etc.), the pioneers of the leadership remained anonymous and found their place in the history of tourism and mountain climbing. This article omits the subject of Tatra guides, which will be the subject of a separate study.

Od momentu, gdy człowiek wykształcił w sobie potrzebę poznawania świata i zaczął podróżować, zmieniać miejsca swojego pobytu, gdy odczuł prawdziwą przyjemność płynącą z wycieczkowania, estetycznego przeżywania krajobrazu, kontemplowania widoków, u jego boku pojawił się przewodnik. Wyraz „,przewodnik" uwzględniony został w słowniku 100 tysięcy potrzebnych słów pod redakcją Jerzego Bralczyka i oznaczał osobę, która idąc, wskazuje komuś drogę. W drugim znaczeniu była to „osoba, która zawodowo oprowadza turystów po jakimś terenie". Żeby dobrze uprawiać ów zawód, należy posiadać odpowiednie predyspozycje psychofizyczne i dysponować dużą wiedzą. Jeden ze współczesnych badaczy problematyki turystycznej bardziej doprecyzował pole semantyczne pojęcia ,przewodnik”, dostrzegając w jego osobie

człowieka oznaczającego się specyficznymi kwalifikacjami merytorycznymi (przestrzenna orientacja w danym terenie, znajomość jego realiów i ich historii oraz funkcji), fizycznymi (sprawność, umiejętność poruszania się po tym terenie), dyplomatyczno-perswazyjnymi (umiejętność przekazania podopiecznym najbardziej właściwego sposobu poruszania się w terenie), jak również etyczno-moralnymi związanymi z przejęciem odpowiedzialności za los osób korzystających z jego usług i pomocy².

Etos prawdziwego przewodnika przypominał więc - idąc za takim tokiem myślowym - w bardzo dużym stopniu etos średniowiecznego rycerza, bo łączył je wspólny mianownik, a mianowicie — świadoma realizacja najwyższych standardów etyczno-moralnych, wpływających nie tylko na przyswojenie i uznanie najistotniejszych norm kodeksu moralnego, ale także wynikających ze świadomej realizacji zasady całkowitego poświecenia się, łącznie z oddaniem życia, dla zdrowia i bezpieczeństwa drugiego człowieka.

Zawód przewodnika w nowożytnej Europie prawdopodobnie najszybszemu sformalizowaniu uległ we Włoszech przyciągających turystów antycznymi zabytkami. Jak pisał znawca historii turystyki Antoni Mączak, już w XVII wieku podróżujący spisywał z przewodnikiem vetturino, czyli umowę będącą swoistym pisemnym porozumieniem obu stron. Miała ona stanowić rękojmię zabezpieczającą interesy klienta opłacającego usługę i swoistą obronę przed cwaniactwem, sprytem i niegodziwością najmowanego obcego człowieka.

1 Stownik 100 tysięcy potrzebnych słów, red. J. Bralczyk, Warszawa 2006, s. 668.

2 J. Kolbuszewski, Górskie przewodniki (Uwagi o wspótczesności i tradycji gatunku), [w:] idem, Góry. Przestrzenie i krajobrazy, Kraków 2020, s. 26. 
Dla dziejów kultury nie jest bez znaczenia, że to właśnie ich fantazja [przewodników] kształtowała wyobrażenia o zwiedzanych miejscach, dostarczała starych i nowych legend. Z braku dowodów winy zwolnijmy ich jednak od odpowiedzialności za współpracę z bandytami na drogach. Co prawda najbardziej rozpowszechniony pogląd głosił, że to właśnie wynajmując zawodowego przewodnika, zapewnia się sobie bezpieczeństwo od rabusiów: vetturino był w tym ujęciu nie tyle wspólnikiem bandyty, ile pośrednikiem przekazującym mu okup ${ }^{3}$.

Początek rozwoju wielkiej turystyki przypadł na przełom XVIII i XIX wieku i wtedy też na mapę kontynentu europejskiego naniesiono obiekty ciekawe historycznie, interesujące kulturowo, piękne estetycznie, które winno się zobaczyć. To, co godne było widzenia i zwiedzania, należało utrwalić, ubrać w literacką formę notatki, dziennika, listu czy pamiętnika lub uwiecznić na papierze w formie szkicu, lub przenieść na płótno. Wymagała tego ówcześnie panująca moda i obyczaje podróżowania. Spragnieni silnych wrażeń estetycznych, oczekujący doznań wzrokowo-słuchowych, zaczytani i zainspirowani literaturą romantyczną dostarczającą skrajnych przeżyć emocjonalnych turyści byli skłonni zapłacić każdą cenę, by zaspokoić tego typu potrzeby. Nie licząc się z wydatkami, trudami podróży i innymi niedogodnościami, kierowali swe kroki ku miejscom wyznaczonym na turystycznej mapie, ,zaliczając” kolejne obiekty. Do realizacji programu podróży potrzebowali jednak pomocników, czyli przewodników, ludzi dobrze znających dany teren, konkretne miejsca, którzy za pieniądze ułatwić i umożliwić mogli ich zwiedzanie. Początkowo usługi tego rodzaju wykonywali ludzie przypadkowi, spryciarze, najczęściej tubylcy, wieśniacy wykorzystujący koniunkturę. Bez zupełnego przygotowania, podstawowego wykształcenia, wiedzy i ogłady ci amatorzy oferowali turystom swoją nieprofesjonalną pomoc. Obiekty oznaczone i opisane w popularnej czerwonej książeczce, czyli angielskim przewodniku Murraya, doczekały się więc swoich cicerone, którzy sprawując nad nimi kontrolę, jednocześnie udostępniali je, kierując ruchem zwiedzających. Dla bliższego zilustrowania przebiegu tego zjawiska posłużmy się kilkoma przykładami. John Quincy Adams, przyszły prezydent Stanów Zjednoczonych, zwiedzając w 1800 roku Śląsk, podczas jednej z odbytych wycieczek zahaczył o ruiny Chojnika, po których oprowadził go leciwy przewodnik. Swoje wrażenie amerykański turysta zawarł w liście adresowanym do brata: „Stary człowiek ma klucze i siebie nazywa komendantem zamku. Kiedy zbieraliśmy dziko rosnące maliny na ruinach apartamentów, przyszło nam na myśl, że był on około 200 lat starszy od odkrycia Ameryki"4. Ów przewodnik chyba ze swojego zadania wywiązał się zupełnie dobrze, bo nie tylko turystów oprowadził, ale także przygotował kawę i na zakończenie — zgodnie z panującą ówcześnie modą — zachęcił do złożenia wpisu w wyłożonej księdze pamiątkowej. Z kolei w 1815 roku Józef Morawski,

\footnotetext{
3 A. Mączak, Peregrynacje. Wojaże. Turystyka, Warszawa 1984, s. 49.

4 J.Q. Adams, Listy o Śląsku, wstęp W. Dynach, Warszawa 1992, s. 42.
} 
absolwent prawa, odwiedzając Śląsk, nie omieszkał zawadzić o ładnie usytuowaną w górskim krajobrazie świątynię wambierzycką. Zwiedzając ów religijny obiekt, skonstatował:

Mniemam, że nigdzie nie umiano stosowniej urządzić wszystkiego, co tylko zmysły i uczucia tego rodzaju podróżnych zająć może. Nie tylko potrzeby życia, ale nawet potrzeby duszy nabożnej stają się tam przedmiotem zysku wielu tej wsi mieszkańców, którzy oprowadzając ich [turystów] po stacjach, kaplicach, kapliczkach, grotach, pagórkach, dolinach i lasach poświęconych, nie tylko prawdziwymi są cicerone, ale nawet na każdym miejscu odczytują stosowne im cudy, przyśpiewują z nimi pieśni, przewodniczą im w wyborze modlitwy, zgoła jak najgłębiej wpajają w nich miejscowe wrażenie ${ }^{5}$.

W tym konkretnym przypadku można było mówić o nieformalnej grupie przewodników-amatorów, którzy znaleźli sprytny sposób na zarobienie pieniędzy. Miejsca lokalnego kultu stały się źródłem dobrego i intratnego interesu. Mieszkańcy wsi w żadnym przypadku nie byli przygotowani do pełnienia funkcji przewodników, co nie przeszkadzało im w wykorzystaniu popytu na tego typu usługi. W kilka lat później odwiedzający zupełnie inne miejsce Józef Ignacy Kraszewski narzekał i na coś zupełnie innego: „Ludzie oprowadzający nie umieli nam objaśnić ani o portretach, ani o popiersiach, kogo mianowicie wyrazić miały"6. Goszcząca w latach czterdziestych XIX wieku w Szczawnie Anna Nakwaska zawitała do zamku Książ. Oczyma duszy widziała witającego gości dumnego dziedzica otoczonego żołnierzami i giermkami, ale rzeczywistość okazała się bardziej prozaiczna:

Zamiast tego [...] zastaliśmy w sieni młodą rumianą ślązaczkę w skrzydlatym czepku i kusej odzieży, która z pękiem kluczy w ręku za cicerone służyć nam się ofiarowała, a oprowadzając nas po wszystkich komnatach i tajnych zakątkach tej siedziby, lekcję swoją jakby ptak na pozytywce uczony w każdym miejscu jednostajnie powtarzała, nie zważając na to wcale, żeśmy często od spróchniałych krzeseł i zakopconych chorągiewek wzrok nasz do okien, z których najpiękniejsze widoki nam się przedstawiały, zwracali ${ }^{7}$.

Zapewne owa sytuacja nałożyła się Nakwaskiej na inne wspomnienia. Kilka lat wcześniej odbyła ona bowiem podróż do Szwajcarii, w trakcie której między innymi należało odwiedzić - utrwalony w literaturze romantycznej — pięknie położony nad Lemanem zamek Chillon. Wraz z grupą turystów dotarła do opisanego w powieściach poetyckich, pełnego grozy obiektu i tak opisała jego zwiedzanie:

5 J. Morawski, Podróż w Śląsku w roku 1815 opisana w listach do brata, [w:] Polskie podróże po Ślasku w XVIII i XIX wieku (do 1863), oprac. A. Zieliński, Wrocław 1974, s. 100.

6 J.I. Kraszewski, Wspomnienia Odessy, Jedyssanu i Dudzaku, Warszawa 1985, s. 58.

7 A. Nakwaska, Wspomnienie krótkiej podróży 1844 roku, [w:] Polskie podróże..., s. 195. 
Tam czekała już na nas jakaś szczebiotliwa, wesoła, już nie młoda, ale tak jak każda francuska, nigdy niestarzejąca się, odźwiernego żona z pękiem ogromnych kluczy i stałym przedsięwzięciem, nieprzypominania żadnego szczegółu, niedarowania nam żadnej przed 5ciuset laty tu wydarzonej okropności ${ }^{8}$.

Owa przewodniczka z lubością prezentowała turystom miejsca będące w przeszłości świadkami tortur i przemocy, a wszystko po to, by wywołać w nich poczucie lęku, irracjonalnego strachu. Ostatecznie cel został osiągnięty, albowiem „taką zgrozą nasze towarzystwo napełniła, żeśmy wszyscy zgodnie opuszczając szybko więzienie, o zwiedzanie innych części zamku ją poprosili" 9 . Z kolei w Ferney, posiadłości należącej kiedyś do Woltera, oprowadzał Nakwaską stary ogrodnik, który

odtąd na krok nie odstąpił, pókiśmy nie wyczerpali jego wszystkich dowcipnych i niedowcipnych anegdotek, nie przejrzeli i nie nabyli drobnych po sławnym Wolterze pamiątek; słowem — póki nas znużonych i przesyconych dowcipem i pyłem przeszłego wieku do powozów nie powsadzał [...]. Opowiadanie tego starca było podobnym do śpiewu kanarka, podług nauczającej go pozytywki; ktoś mu te historyjkę dobrą francuszczyzną napisał, a on ją od lat 40 powtarza. Życzę szczerze, żeby mu nigdy nie zabrakło powolnych do słuchania jego uszów ${ }^{10}$.

Dwukrotne użycie przez Nakwaską porównania głosów osób oprowadzających, po bardzo przecież interesujących obiektach turystycznych, do monotonnych ptasich treli nie świadczyło na korzyść tych pierwszych. Przewodnicy operowali schematami, kalkami, brakowało im profesjonalizmu, nie byli w stanie nawiązać kontaktu ze zwiedzającymi i te niedociągnięcia dawały się odczuć na każdym niemal kroku. Przebywający we Włoszech Józef Ignacy Kraszewski bardzo szybko uświadomił sobie, że w tym kraju nic nie da się zobaczyć i zwiedzić, nie opłaciwszy się - i tu wymienił jednym ciągiem - custodom, przewodnikom, klucznikom, ciceronom. Podczas zwiedzania grobu Wergiliusza on i jego towarzysze zbyt nisko wycenili usługi przewodnika, a ten zareagował w sposób dość osobliwy. Opisywał Kraszewski: „Jął się unosić, rzucać, miotać, krzyczeć, śmiech nas obudzał w nim coraz większe oburzenie, tarł czapkę, tupał nogami, gonił nas, nic nie pomagało, został przy tym carlinie"ll. Carlin, czyli ówczesna włoska jednostka monetarna, była, według niego, zapłatą nieadekwatną w stosunku do wykonanej pracy i poczucie niesprawiedliwości, czy może raczej chciwości oraz pazerności, stało się przyczyną jego niepohamowanej złości. Inaczej zachowującego się przewodnika zatrudnił Włodzimierz Budzyński, który na

\footnotetext{
8 A. Nakwaska, Wspomnienie podróży odbytej roku 1837, „Przyjaciel Ludu” 1838, nr 4-5, s. 30.

9 Ibidem, s. 35.

10 Ibidem.

11 J.I. Kraszewski, Kartki z podróży 1858-1864, t. 2, oprac. P. Hertz, Warszawa 1977, s. 46.
} 
alpejską wycieczkę wynajął osobę rekomendowaną przez biuro przewodnickie. Był „razem patentowanym przewodnikiem i szewcem [...]. Znał, prawda, bardzo dobrze wszystkie ścieżki, lecz nic nie wiedział, nie opowiadał i tylko stojąc w zaznaczonym miejscu i zasłaniając ucho [...], wymawiał przez zęby: »Dziko romantyczny obraz«. Potem obracał się i szedł dalej"12. Ów przewodnik, chociaż nieokrzesany gbur, to jednak postępował i zachowywał się, w swoim mniemaniu, bez zarzutu. Zakładając u swojego podopiecznego potrzebę przeżycia czegoś wyjątkowego, prowadził go w miejsca ładne, widokowo inspirujące, a to, że robił to w sposób prymitywnie prosty, nie było spowodowane bezpośrednio jego winą. Brakowało mu bowiem i profesjonalizmu, i obycia towarzyskiego, czyli znajomości zasad dobrego zachowania, ogłady czy kultury. Nie należy więc dziwić się temu, że Budzyński pod adresem przewodników, ich ignorancji i braku kompetencji do wykonywania tego trudnego zawodu sformułował bardzo konkretną listę zarzutów:

Szkoda jednak, iż ukszałcenie ich nie odpowiada bynajmniej ciekawości podróżnego, którego tylko prowadzą, a tak [...], gdzie droga nie przedstawia żadnego niebezpieczeństwa, można by się bez nich obejść zupełnie. Nie szukają sami, lecz czytając (i to z nich czyni niewielu) Ebla, mówią to samo, czego podróżny w samejże książce dowie. Szkoda, iż gdy liczba ich i zarobek tak znaczny, nie ma jakiegoś zakładu, z którego by patentowymi wychodzili1 ${ }^{13}$.

Niejednokrotnie uprzedzano turystów przed grożącymi im ze strony źle dobranych przewodników różnego rodzaju nieprzyjemnościami. Wysiadający na grecki ląd Tadeusz Padalica miał w uszach przestrogę kapitana statku, aby nie tracić czujności i dobrze pilnować przed kradzieżą swój bagaż. Kierowany pierwszym impulsem na swego przewodnika wynajął człowieka obdarzonego przez naturę ,,sprytnymi oczyma” i „kozackim wąsem”, z pochodzenia Ukraińca, który dobrze znał Smyrnę i podjął się oprowadzenia. Główną atrakcją turystyczną była wyprawa na szczyt góry Pagus, na której najciekawszym do zwiedzenia obiektem okazały się ruiny zamku i przynależne do nich lochy. Te ostatnie, mroczne i tajemnicze, wyzwalały specyficzną atmosferę grozy, wywoływały w zwiedzających niepokój. Padalica penetracji podziemi dokonywał w towarzystwie wybranego przecież dość przypadkowo człowieka. O swojej narastającej w miarę upływu czasu nieufności pisał:

Gdyśmy się zaczęli spuszczać w lochy i zagłębiać pod ciemne sklepienie ruin, wyznaję, że zacząłem powątpiewać w cnotę mojego przewodnika i rewolwer mój w pogotowiu trzymałem w kieszeni [...]. Chciałem usiąść na odkrytym miejscu, ale mój cicerone zachęcił mnie wejść

12 W. Budzyński, Niemcy i Szwajcaria, t. 1, Wilno 1856, s. 23.

13 Ibidem, t. 2, s. 86. 
pod sklepienie. Żeby nie dać pozoru nieufności, usłuchałem rady jego, i w razie niebezpieczeństwa, obmyślałem dobrze, jak mam postąpić ${ }^{14}$.

Ostatecznie okazało się, że obawy były nieuzasadnione, a sam przewodnik był człowiekiem zapobiegliwym, opiekuńczym i dobrze wywiązał się z podjętego zadania.

Jednakże w dziejach turystyki zanotowane zostały sytuacje tak dramatyczne jak zamordowanie niemieckiego turysty wchodzącego na Wezuwiusz; od tego czasu turyści korzystali ze zbrojnej eskorty, o czym wspominał Michał Wiszniewski w relacji z podróży do Włoch. Negatywnych emocji doświadczył też przywoływany już wcześniej, Kraszewski, który wraz z grupą towarzyszy postanowił odbyć wycieczkę na szczyt Wezuwiusza. Dotarcie do wulkanicznego krateru bez fachowej pomocy raczej nie wchodziło w rachubę, stąd zrodziła się konieczność zatrudnienia przewodnika. To oczywiście wiązało się nie tylko ze sporym wydatkiem, ale także niepewnością co do doboru odpowiednich osób. Już od samego początku wynajęci do bezpiecznego asekurowania i przeprowadzenia karawany ludzie zaczęli wzbudzać niepokój. Matacząc przy wyborze drogi, piętrząc problemy, budowali atmosferę pełną lęku i napięcia. Pisał Kraszewski: „Czy omijając gorsze jakieś miejsca, czy żeby nimi nastraszyć tylko, przewodnicy ogromnie krążą i nakładają drogi. Interesem też jest spekulantów, którzy mają później wnosić, wciągać i popychać podróżnego na wierzchołek, żeby zaraz wszystko utrudniać, okazywać jak najstraszniejszym i znużyć wędrowca"15. Wezuwiusz i Etna stanowiły dla tubylców żyłę złota, gdyż zainteresowanie, jakim sie cieszyły, przełożyć można było na stały przepływ pieniędzy. Oba te wulkany dawały siłę napędową włoskiemu przemysłowi turystycznemu, bo każdy chciał na tym zarobić. Turyści, nie marudząc, kupowali każdą usługę, płacąc za nią słono, a już w szczególności za przewodników, którzy byli gotowi zrobić wszystko, by doprowadzić zainteresowanych na szczyt. Ciągali, szarpali, poszturchiwali, nawet wnosili, gdy była taka potrzeba. Dla kobiet i osób słabszych przygotowano lekkie krzesła, które obsługiwało czterech osiłków: „Krzesło dość drogo kosztuje, a są tacy, co nimi gardzą od razu i muszą je dopiero wziąć, gdy już tchnąć nie mogą"16. Dla wielu wyprawa na Wezuwiusza była wielkim wyzwaniem, gdyż droga do przebycia zdawała się ekstremalnie trudna. W miarę podchodzenia u osób mniej doświadczonych w górskich eskapadach, a ci stanowili większość, narastało coraz większe zmęczenie i górę zaczynały brać negatywne emocje. Tak reagował towarzysz Kraszewskiego, który, „klnąc Włochy, Wezuwiusz, drogę, przewodników, ciekawość niepotrzebną i co tylko przełknąć się dawało, pochwycił także pasek opiekuńczy [przewodnika] i szedł, nie przymierzając, jakby go na rzeź ciągniono"17. Podróżnym męcząca wspinaczka odbierała całą

14 T. Padalica [Z. Fisz], Listy z podróży, t. 3, Wilno 1859, s. 56-57.

15 J.I. Kraszewski, Kartki..., s. 139.

16 Ibidem, s. 141.

17 Ibidem. 
radość i przyjemność, jaką zazwyczaj czerpali z wycieczki. Ciągnięci na paskach przez przewodników nie byli w stanie oddać się kontemplacji piękna krajobrazu i podziwiania roztaczających się widoków. Ci zaś, którzy pozwolili się nieść na krzesłach, całą swoją uwagę koncentrowali na takim balansowaniu ciałem, by uniknąć zetknięcia z ziemią. Krzesło bowiem w trakcie niesienia stawało się niestabilne, kołysało się na różne strony, co groziło upadkiem. Gdy wreszcie po pokonaniu ciężkiej drogi udało się osiągnąć szczyt, podróżni zatracali instynkt samozachowawczy i nie zważając na nic, zbliżali się do krateru wulkanu, ulegając fascynacji ziejącym z czeluści ogniem:

Nachylając się od brzegu, oko sięgało dalej, chociaż przewodnicy ostrzegali, aby się, nadto dowierzając skorupie, nie zbliżać, gdyż czasem obłamywać się umie ${ }^{18}$.

Najsilniejsze wrażenia czekały turystów w drodze powrotnej, podczas schodzenia w dół. Przewodnicy zarządzali odwrót w momencie, gdy zaczął zapadać zmierzch i krajobraz stawał się coraz bardziej demoniczny. Gęstniejący mrok wyeksponował czerwień lawy, co potęgowało nastrój metafizycznego lęku. Do tego dochodziło ogólne zmęczenie fizyczne, które zaczynało dominować nad rozwagą oraz rozsądkiem. Relacjonował Kraszewski:

Część tej drogi dramatyczniejszą była może niż pierwsza, byliśmy bowiem na łasce ludzi nieznanych, wśród nocy, na pustkowiu [...]. Przy tym zgraja naszych towarzyszów, która dość długo nas przeprowadzała, po zapłacie stała się coraz bardziej zuchwalszą; główny przewodnik objawił życzenie wracania krótszą drogą, na co zezwolić nie mogłem ${ }^{19}$.

Lęk o życie był na tyle duży, że jeden z turystów w akcie determinacji wyciągnął z kieszeni parę nabitych pistoletów, co znacznie uciszyło agresorów. Szef przewodników pod groźbą użycia broni zmuszony został do sprowadzenia karawany bezpieczniejszą, bo łagodniej opadającą drogą, ale całkowitego rozejmu strony do końca nie osiągnęły. Płynące żądania finansowe adresowane do turystów połączone były ze słownymi pogróżkami. Ostatecznie przewodnicy rozsierdzeni brakiem reakcji na swoje finansowe roszczenia długo gonili uciekających przed nimi ludzi. Opisane sytuacje w cywilizowanym kraju nigdy nie powinny mieć miejsca, ale wielokrotnie dochodziło we Włoszech do podobnych epizodów, co związane było z dysfunkcyjnością ówczesnego przemysłu turystycznego. Brak odgórnej regulacji ruchu turystycznego, panujący powszechnie chaos i samowola, niekontrolowany przez nikogo wyzysk podróżnych, chciwość granicząca z pazerstwem oraz cwaniactwo przewodników nieprzynoszących chlub temu fachowi - to tylko niektóre anomalie, z którymi nikt nie próbował walczyć. Zachowanie przewodników było skandaliczne, nieprofesjonalne, bo wykorzystując w sposób

18 Ibidem, s. 143.

19 Ibidem, s. 144. 
bezwzględny popyt na swoje usługi, okradali turystów nie tylko z pieniędzy, ale także z pozytywnych doznań i radości płynącej z uprawiania turystyki.

W sąsiadującej z Włochami Szwajcarii przełom XVIII i XIX wieku zapoczątkował formowanie się nowoczesnego, bardziej sprofesjonalizowanego przewodnictwa górskiego. Proces ten związany był z coraz odważniejszą eksploracją wysokich, wiecznie ośnieżonych szczytów, które zdobywano już nie tylko dla potrzeb nauki, ale i własnej satysfakcji oraz przyjemności poznania czegoś nowego. Pod koniec XVIII wieku na górską wyprawę można było już pozyskać ludzi bardzo dobrze obznajomionych z terenem, dziką naturą, odważnych i chętnych do współpracy. Zdrowy rozsądek nakazywał penetrującym Alpy turystom korzystać z usług doświadczonych przewodników, nawet na wycieczki zorganizowane w niższe partie gór. Podróżujący w 1820 roku po Szwajcarii Atanazy Raczyński odradzał zwiedzającym ten kraj nadmierne korzystanie z przewodników książkowych, bez których żaden Anglik nie mógł się obejść. Uważał, że dla podróżnych są one zupełnie bezwartościowe, a w prowadzonym dzienniku podróży pisał:

Przekonałem się, że nie warto radzić się przewodnika, oni posługują się schematem, który pewno został ustalony w obawie przed kosztami i fatygą; ten rytuał jest jak najmniej korzystny dla podróżującego, który chce jak najlepiej wszystko obejrzeć. Trzeba się samemu urządzić tak, aby nie ponosić większych kosztów ${ }^{20}$.

Względy ekonomiczne nie odgrywały roli wtedy, gdy w rachubę wchodziło bezpieczeństwo wyprawy, i dlatego wybierając się w wyższy szczyt, korzystał Raczyński z usług profesjonalistów: „Z wielkimi laskami, okutymi żelazem, szliśmy gęsiego, jeden za drugim, wspinając się w górę od Chamonix. Stąd nie było widać Mont Blanc. Prowadzili nas przewodnicy, pomagając w najtrudniejszych miejscach" 21 . Wchodząc w obręb gór, należało liczyć się ze śmiercią, czego symbolem było mortuarium klasztorne przy Wielkiej Przełęczy Świętego Bernarda. O dramacie, który się tam rozegrał, opowiadał turystom jeden z przewodników alpejskich: „Patrzcie panowie, na tym samym kamieniu, gdzie teraz spoczywacie, znaleźliśmy owego młodzieńca za marca roku zeszłego i wskazał na porządnie ubrane ciało" 22 . W obliczu tak konkretnego, niemal namacalnego przykładu bliskości śmierci romantycznemu podróżnikowi pozostawała tylko smutna zaduma i głęboka refleksja: „Spoglądając na drogę przebytą, nie mogliśmy się dość wydziwić śmiałości tych, co bez przewodnika podróż tę przedsiębiorą, tam, gdzie ani drogi bitej nie ma i gdzie łatwo zbłądzić można"23.

20 A. Dobrzycka, Atanazy Raczyński w Alpach. Fragmenty pamiętników, „Wierchy” 56, 1987, s. 80 .

${ }^{21}$ Ibidem, s. 68.

22 A.K., Utamek podróży po Szwajcarii, „Przyjaciel Ludu” 1839, nr 36, s. 287.

23 Ibidem, s. 287. 
Ekstremalnie trudną podróż alpejskimi przełęczami odbyła Eliza Krasińska, żona Zygmunta, która później, jesienią 1851 roku wraz z dziećmi podążała do Genui. Obawa o życie swoje i najbliższych nie opuszczała jej na moment, a całą wyprawę traktowała jako jedną wielką odyseję, walkę o przetrwanie. Jednocześnie nadzieję na szczęśliwe zakończenie eskapady pokładała w Bogu i towarzyszących jej przewodnikach. W liście adresowanym do siostry tym ostatnim nie szczędziła słów pochwały i uznania. Przewodnicy dawali bowiem gwarancję w miarę bezpiecznego i spokojnego przejazdu górskimi drogami. Krasińska podziwiała ich zaangażowanie, odpowiedzialność, zręczność. Uspokajająco działała na nią myśl, że w razie jakiejkolwiek katastrofy wozu przewodnicy pospieszą z natychmiastową fachową pomocą i dlatego z pełnym przekonaniem pisała, że pozwoliła się prowadzić i zaufała tym dobrym ludziom. Przewodnicy zaś, mając to na uwadze, robili wszystko, aby przeprawa przebiegała sprawnie i bez zakłóceń. Doceniła ich starania Krasińska, pisząc: „Nasi przewodnicy (prawdziwi aniołowie wybawiciele, gdyż trudno mi opisać, jak się nami opiekowali i jak nam byli oddani), dzielni Mullerowie, dwaj młodzi ludzie inteligentni i odważni" ${ }^{24}$. Ci prości górale nie byli w tym przypadku ludźmi anonimowymi, bo ich nazwisko pojawiło się w prywatnej korespondencji, a to, że się pojawiło, było najlepszym dowodem szacunku i uznania za perfekcyjne wywiązanie się z obowiązków, które na siebie wzięli.

Już w drugiej połowie XVIII wieku zaobserwować dało się zjawisko wyodrębnienia stałej grupy ludzi, którzy będąc dobrze zorientowani w alpejskiej topografii, mając dużą sprawność fizyczną, oferowali, za opłatą, swoje usługi coraz to liczniejszemu gronu zagranicznych turystów, wprowadzając ich na najwyższe szczyty. Ich górskie doświadczenie przekładało się na zwiększenie bezpieczeństwa wypraw. Do obowiązków przewodników należała pomoc w organizacji eskapady, a następnie pilotowanie jej od momentu wyjścia, aż do szczęśliwego powrotu. Profesja ta najczęściej później przechodziła z ojca na syna, a ze względu na osiadły tryb życia górali uprawiali ją ci, którzy mieszkali w miejscowościach najbliżej tych gór położonych, jak na przykład Chamonix. W historii alpinizmu zauważyć dawało się powtarzalność pewnych nazwisk i miejscowości do nich przypisanych. Nestor rodu Jacques Balmat wsławił się kilkukrotnym wejściem na Mont Blanc, góry przez wieki uważanej za niedostępną. Zdobyciem najwyższego w Europie szczytu zainteresowanych było wielu naukowców, badaczy i turystów. Do jednego z pierwszych myślących o wejściu na Mont Blanc zaliczyć można profesora Horacego-Bénédicta de Saussure'a, który w 1785 roku zorganizował wielką na ów czas wyprawę. W ekspedycji towarzyszyło mu 11 przewodników i kilku tragarzy obciążonych ogromnym ładunkiem. Świetnie zaopatrzona, jak na swoje możliwości, wyprawa dotarła bardzo wysoko, ale z powodu zbyt śnieżnego opadu nie zdecydowano się na ostateczny atak szczytu. Znacznie wyżej, ale nie na sam wierzchołek, dotarło dwóch przewodników: Balmat i nijaki Couidet. Gdy dla Saussure'a owa wyprawa była porażką, dla alpejskich górali — zwycięstwem

24 Z. Sudolski, Polski list romantyczny, tu: list Elizy Krasińskiej do Katarzyny Potockiej, Kraków 1997, s. 439-440. 
i doskonałym sprawdzianem swoich możliwości fizycznych oraz umiejętności wspinaczkowych. Ponadto udowodnili oni, że w sprzyjających warunkach pogodowych zespołowe zdobycie Mont Blanc może stać się już wkrótce bardzo realne. Swoje umiejętności potwierdził Balmat rok później, gdy w towarzystwie Michaela-Gabriela Paccarda stanął na samym szczycie wspomnianej góry. 8 sierpnia 1786 roku jeden z turystów - baron von Gersdorf - obserwujący przez lornetkę Mont Blanc odnotował w swoim dzienniku, że „ujrzał, jak dwie postacie weszły na szczyt. Pierwszy wszedł doktor, tuż za nim Balmat"25. To wspólne wejście było jednak kwestionowane i negowane przez dziesiątki lat. Opinia publiczna zgodziła się przydać palmę pierwszeństwa wejścia na Mont Blanc prostemu, niegroźnemu dla nikogo góralowi z Chamonix, bo to nie podważało naukowych autorytetów. Inaczej rzecz się miała $z$ doktorem Piccardem, który odebrał zwycięstwo ambitnemu de Saussure'owi czy jego rywalowi Théodore'owi Bourittowi. W tym przypadku górę wzięły ludzkie animozje, złe emocje czy zazdrość połączona z zawiścią odbierające doktorowi to, co mu się słusznie wtedy należało. Musiało minąć około 200 lat, by odmitologizując historię alpinizmu, przyznać wygraną Piccardowi i uznać wejście jego i Balmata w 1786 roku za pierwsze zdobycie Mont Blanc.

Na tych waśniach i sporach uczonych nie ucierpiał, a raczej skorzystał, Balmat, bowiem zdobycie Białej Góry bardzo dobrze wykorzystał w najbliższych latach. Z rąk de Saussure'a odebrał nagrodę pieniężną (wyznaczoną przez samego profesora za pierwsze wejście na szczyt), zyskał sławę i poważanie. W następnym roku, czyli 1787, był jednym z 17 przewodników, którzy pod przewodnictwem de Saussure'a ponownie ruszyli na Mont Blanc. Sam profesor, chcąc zablokować i znokautować działania konkurencji, na wyprawę zatrudnił wszystkich górali z Chamonix trudniących się przewodnictwem. Góra ostatecznie została zdobyta, zaś to wydarzenie nabrało historycznego znaczenia dla dalszego rozwoju alpinizmu ${ }^{26}$. Upamiętniono wejście pomnikiem postawionym 100 lat później w centralnym miejscu Chamonix, na którym przedstawiono profesora de Saussure'a i ,jego" przewodnika Balmata. Ten ostatni stał się symbolem górala zasłużonego dla rozwoju alpinizmu. Ciekawostką jest to, że Balmat był także poszukiwaczem złota i górskich kryształów i to zajęcie stało się przyczyną jego tragicznej śmierci, gdyż zginął w 1834 roku, w trakcie eksploracji minerałów. Za swoje zasługi, już za życia obdarzony szacunkiem i ogromnym poważaniem, stał się legendą. Najwymowniejszym przykładem docenienia jego zasług było nadanie mu przez księcia Sabaudii prawa do używania nazwiska Balmat de Mont Blanc. W następnych latach kilkakrotnie towarzyszył on innym turystom chcącym zdobyć najwyższy alpejski szczyt. Miał także w swoim ciekawym życiu epizod związany z Polską. Towarzyszył bowiem w wyprawie na Mont Blanc Antoniemu Malczewskiemu, a była to jedna z pierwszych odnotowanych ekspedycji zakończonych sukcesem. Malczewski dokonał tego wielkiego wyczynu

${ }^{25}$ Cyt za: B. Chwaściński, Mont Blanc. Zdobycie szczytu, „Wierchy” 32, 1963, s. 93.

${ }^{26}$ Zob. ibidem. 
w 1818 roku, a sprawozdanie $\mathrm{z}$ wyprawy, napisane w formie listu, złożył na ręce profesora Augusta Picketa, który opublikował je na łamach jednego z naukowych czasopism wydawanych ówcześnie w Genewie. W liście pisał:

Trzy dni pogody bez najmniejszej chmury i niezbyt rozmiękłe śniegi prawie potrzebniejszą pomocą niż najcierpliwsza wytrwałość i najmocniejsze piersi; bez tych jednak warunków tylko na zgubę narazić się można i byłoby najszkodliwszym uporem nie słuchać ostrzeżeń przewodników, którzy wszędzie w Szwajcarii, a szczególnie w Chamonix, pełni są odwagi i rozsądku ${ }^{27}$.

Te proste i szczere słowa najwymowniej świadczyły o ogromie szacunku, jaki miał Malczewski w stosunku do towarzyszących mu w drodze na szczyt górali alpejskich, bo doskonale zdawał sobie sprawę z tego, że bez ich pomocy nie zrealizowałby postawionego sobie celu. Bezpośredni dowód w postaci jednej z pisemnych pozytywnych opinii odnaleziony został po prawie 100 latach, gdy dociekliwy badacz historii turystyki alpejskiej wydobył starą książeczkę przewodnicką należącą do uczestnika wyprawy z następującym wpisem zrobionym ręką Malczewskiego: „Jean-Michel Balmat był ze mną na Aiguille du Midi i na Mont Blanc. Polecam go jako bardzo dobrego przewodnika, silnego i rozważnego"28.

W dziesięć lat później do małego Chamonix przybył inny Polak - Michał Podczaszyński, dziennikarz, współzałożyciel „Dziennika Warszawskiego”. Podróżował on po Szwajcarii, a swoje wrażenie ubierał w formę epistolograficzną. Dla nas najciekawszy okazał się list opublikowany w 1827 roku w „Gazecie Polskiej", w którym opisywał dwa interesujące epizody. Pierwszy z nich miał miejsce w oberży, drugi dotyczył bezpośrednio spotkania z legendarnym już wówczas Balmatem. W oberży usłyszał Podczaszyński interesującą rozmowę, którą toczyli ze sobą nieznani mu zagraniczni turyści. Jeden z rozmówców napomknął o tragicznym wydarzeniu sprzed trzech lat, gdy „trzech przewodników prowadzących dwóch Anglików wpadło w przepaść śniegową na parę tysięcy stóp głęboką"29. Opowieść ta wywarła silne wrażenie na przysłuchujących się jej dwóch młodzieńcach, którzy nieomal natychmiast zdecydowali się na zorganizowanie podobnej ekspedycji. W tym celu wysłano po przewodników, a dalszy rozwój wydarzeń wyglądał następująco: „Przyszło dwunastu ludzi: dziesięciu zgodziło się po 140 złotych od osoby, dwóch zaś, którzy zwykli iść naprzód i próbować długimi tykami, czyli nie masz ukrytych pod śniegiem przepaści, a zatem którzy się narażali na największe niebezpieczeństwo, dostali po 240 złotych"30. Wyprawę zorganizowano i młodym ludziom udało się wraz z przewodnikami

27 A. Malczewski, Podróż na górę biała (Mont-Blanc), opisana w liście do profesora Picteta, „Dziennik Wileński” 1818, nr 11, s. 486-493.

28 Zob. B. Chwaściński, op. cit., s. 105.

29 Z. Przychodniak, Dwie wiadomości o Antonim Malczewskim w prasie warszawskiej z 1826 i 1837 roku, „Pamiętnik Literacki” 76, 1985, nr 2, s. 261.

30 Ibidem, s. 262. 
dotrzeć na szczyt, ale czy obyło się bez śmiertelnych ofiar, tego już Podczaszyński nie wiedział. Niewykluczone, że mogło do tragedii dojść, gdyż mniej członków ekspedycji miało schodzić, niż podchodzić do góry. Drugi opisany epizod dotyczył rozmowy Podczaszyńskiego z Jakubem Balmatem:

Tenże sam Balmat był na Mont Blanc z naszym ziomkiem Malczewskim. Ciekawy byłem coś usłyszeć o tej podróży. Ale stary gaduła tak drobił, tak siekał szczegóły, że z całej rozmowy to tylko mogłem wycisnąć, że zacny Malczewski bardzo się jemu podobał, że jest bardzo dobry pan i że pił wiele limoniady, ponieważ na takiej wysokości ustaje apetyt, a wzrasta pragnienie ${ }^{31}$.

W 1839 roku pojawiła się w „Dzienniku Ludu” drukowana w odcinkach relacja z wejścia na Mont Blanc. Anonimowy autor bardzo interesująco i w miarę szczegółowo opisał przebieg wyprawy od momentu werbowania przewodników, aż po osiągnięcie szczytu. W pierwszej kolejności ambitni turyści uzyskali zgodę na udział w eskapadzie Michała Balmata, wnuka zasłużonego Jakuba, kierując się zapewne przeświadczeniem, że nazwiskiem tym, jako swoistego rodzaju marką, zagwarantowane zostanie bezpieczeństwo i sukces całego przedsięwzięcia. Michał, jak podkreślał autor relacji, zresztą najmłodszy wiekiem członek ekipy — za pozwoleniem innych przewodników - wybrany został „naczelnikiem” wyprawy, ale postawił jeden zasadniczy warunek:

Poprosił nas [...] o pozwolenie udania się do domu, dla zabawienia się reszty dnia $z$ rodziną i urządzenia niejednego na wszelki przypadek. Inni przewodnicy to samo oświadczyli; nie nadmieniali razem wprawdzie ani słowa o niebezpieczeństwie wyprawy, mowa ich atoli stała się poważniejszą, ich rysy przybrały coś uroczystszego. Niezadługo potem zebrali się koło, mówili coś z cicha do siebie i oddalili się w milczeniu ku mieszkaniom ${ }^{32}$.

Ten moment skupienia i zadumy był rzeczą zupełnie naturalną, bo każda tego typu wyprawa wiązała się z konkretnym ryzykiem, zagrożeniem lub nawet utratą życia. Już więc w momencie wymarszu przez przewodników narzucony został szyk, w jakim postępować winni uczestnicy ekspedycji. Tego układu, w trosce o bezpieczeństwo swoje i innych, należało bezwzględnie przestrzegać. Konwój otwierało sześciu tragarzy (maszerowali oni tylko do pewnego, z góry określonego miejsca), za nimi gęsiego postępowało sześciu przewodników, trzech uczestników wyprawy i kolejnych czterech przewodników. Ekspedycja żegnana była przez tłum ludzi, w tym dzieci i krewnych odchodzących górali. Najmłodszym uczestnikiem wyprawy zaopiekowano się w sposób wyjątkowy. Gdy tylko udało się dotrzeć do pierwszego lodowca, dwóch najbardziej doświadczonych przewodników, a mianowicie - Michał Balmat i David Folliquet — przejęło nad nim

31 Ibidem, s. 263.

32 Najnowsza podróż na górę Mont Blanc, „Przyjaciel Ludu” 1838, nr 42, s. 329. 
całkowitą kuratelę. I chociaż młodzieniec jeszcze przed rozpoczęciem wyprawy deklarował, iż jest ,gotów oddać się zupełnie przewodnikom moim, jako ludziom odważnym, przezornym i pewnym przytomności umysłu"33, ci autorytatywnie przypomnieli mu o potrzebie działań komplementarnych. Folliquet układ ten ubrał w słowa proste, acz bardzo dosadne: „Teraz, mój młody panie, nie znajdziesz bezpieczeństwa, jak w zupełnej ufności we mnie". Odpowiedziałem, iż nigdy dotąd na lodowatą górę nie wstąpiłem i że całą ufność w nim pokładam. Potem dodał: „Ściskamy nasze dłonie na znak przyjaźni, i umilkł, stają się bowiem przewodnicy małomówni, skoro niebezpieczeństwo zagraża, celem zebrania całej uwagi" 34 . Już wkrótce koincydencja wydarzeń w pełni uzasadniła sens owych słów. W momencie najmniej spodziewanym młody turysta gwałtownie poślizgnął się na rozmiękłym śniegu, gdy pod jego nogami znajdowała się otwarta, do tego najeżona stalagmitami czeluść. Przygotowany na tego typu sytuacje przewodnik, nie tracąc na moment zimnej krwi, otoczył ciało młodzieńca postronkiem i ciągnąc za kołnierz, silnym ruchem przerzucił go na drugą stronę szczeliny. Od tego też momentu niedoszła ofiara bez szemrania przypięta sznurem postępowała za swoim opiekunem. Zmieszczone w kolejnych numerach „Przyjaciela Ludu” odcinki, będące swoistą formą relacji z przebiegu wyprawy, zapewne dostarczały potencjalnemu czytelnikowi sporo informacji na niebanalny temat. Młody autor przejawił niewątpliwy talent literacki, opisując klimatyczny alpejski krajobraz, zmaganie człowieka z żywiołem i niebezpieczeństwa czyhające podczas wspinaczki itd. Dużo też serca oraz uwagi poświęcił pracy przewodników, którzy nie tylko ponosili odpowiedzialność za bezpieczeństwo turystów, ale także w ramach swoich obowiązków musieli zabezpieczyć minimum egzystencjonalne: aranżować miejsca postoju i wypoczynku, organizować biwaki, rozniecać ogień, warzyć strawę. Podczas trwania marszruty nie tylko wyznaczali najbezpieczniejszą trasę, lecz także wykuwali w lodzie schody, asekurowali idących, pomagali pokonać lodowe szczeliny. Do tego dochodziła obawa o niespodziewane obsunięcie się śnieżnych nawisów. Lawinę mógł wywołać ludzki głos, jak i przechodzące dzikie zwierzęta. Jeden z przewodników podczas postoju przypomniał tragiczną historię sprzed kilku lat, gdy schodzące ze stoku wały śniegu zasypały nijakiego Hammela i trzech towarzyszących mu górali. Sam będąc świadkiem owego wydarzenia, tak to zapamiętał: „Julian Devouassony, przewodnik z nami teraz się znajdujący, także nią wtedy porwany został, jednakowo cud go tylko od śmierci uratował, której inni trzech ulegli. Milcząc, wskazał nam miejsce, gdzie jego towarzysze, porwani lawiną, znaleźli grób w otchłani" 35 . Opisany wypadek nie tylko wiele mówił o niebezpieczeństwie czyhającym w górach, ale był doskonałym przykładem ilustrującym widmo śmierci towarzyszącej pracy przewodnika.

Zapewne o sprawach ostatecznych nie rozmyślał inny młody człowiek, jeden z bohaterów dzieła Podróż nad Renem i w Szwajcarii Stanisława Egberta

33 Ibidem, s. 329.

34 Ibidem, s. 330.

35 Ibidem. 
Koźmiana, który postanowił zdobyć górę Kamor, a do zrealizowania tego pomysłu potrzebny był mu górski przewodnik. Ta eskapada, jako pewnego rodzaju inicjacja w dorosłość, miała być perfekcyjnie zorganizowana, dopięta na ostatni guzik i pod każdym względem widowiskowa. Wynajęty przewodnik musiał ubrać się w ludowy strój kantonu appenzelskiego i zabrać ze sobą instrument muzyczny: „Nazajutrz więc o świcie zagrał przed naszymi oknami na alpejskiej fujarze czy trąbie poranną pieśń alpejską Johann Gabriel Törick, przywdziany świątecznie w ubiór swojego kantonu: spodnie czarne, kamizelka czerwona, strojna koszula i krótkimi rękawami ozdobiona szelkami, a na głowie czerwona czapeczka" ${ }^{36}$. W drodze wygrywał turystom na długiej fujarze smętne pieśni ludowe, wzbudzając tym żywe zainteresowanie gapiów, którzy przesyłali wędrującym pozdrowienia i udzielali bożego błogosławieństwa. Nikogo nie dziwiła teatralna oprawa, ubiór przewodnika, muzyka, bo to wszystko wkomponowane było w rytuał dziewiętnastowiecznych ekspedycji. Autor był dobrym obserwatorem, bo zawarł w swej narracji sporo spostrzeżeń i uwagę natury socjologicznej. Zauważył on między innymi prawidłowość w rodzinach górali alpejskich polegającą na przekazywaniu z pokolenia na pokolenie profesji przewodnika. O sukcesyjnym traktowaniu tego zawodu pisał: „Nie wiem, czy przywilejem, czy tradycją idzie, że urząd przewodników w Szwajcarii zawsze się w jednych utrzymuje rodzinach. Jak w Chamonix naczelne w tym powołaniu stanowisko należy do Balmatów, tak tu do Töricków czy Thoeringów"37. Rodziny te dbały o jakość swoich usług, skrzętnie wypełnianie poleceń najmujących ich turystów, a ich nazwisko stanowiło rękojmię bezpieczeństwa. Szanujący swój fach przewodnicy wyjątkowo dbali o rangę i honor zawodu i gdy tylko cień podejrzenia padał na jakość ich pracy, gotowi byli zrobić wszystko, by ratować własny etos. Odnotował Koźmian historię, która wydarzyła się w 1821 roku. Właśnie wtedy w lodową szczelinę wpadł turysta, a o spowodowanie jego śmierci połączonej, jak przypuszczano, z rabunkiem, oskarżono jednego z towarzyszących mu górali. Pikanterii całej sprawie dodawał fakt, że zaginiony był pastorem. Urażeni w swej dumie, upokorzeni bezpodstawnymi posądzeniami przewodnicy postanowili „wybrać losem jednego pomiędzy siebie, który spuściłby się w rozpadlinie, a jeśli znajdzie ciało pastora, a przy nim pieniądze i zegarek, będzie dostatecznym dowodem, że śmierć była przypadkową" ${ }^{38}$. Przedsięwzięcie zrealizowano, jeden z górali spuścił się na dno szczeliny i odnalazłszy zwłoki, obwiązał je liną, by wyciągnąć je na zewnątrz. W ten sposób nie tylko udało się uratować honor oskarżonego przewodnika, ale także godnie potraktować ciało pastora. Przebieg owej nietuzinkowej akcji znalazł swoje upamiętnienie w epitafijnej formie umieszczonej na grobie tragiczniej ofiary gór.

Możliwość korzystania z usług doświadczonych przewodników nie była wyłącznie domeną krainy alpejskiej. Od przełomu XVIII i XIX wieku przewodnicy

36 S.E. Koźmian, Podróż nad Renem i w Szwajcarii (w 1846 roku odbyte), Poznań 1877, s. 143.

37 Ibidem, s. 299.

38 Ibidem, s. 300. 
górscy pojawiają się w całej Europie, bo bardzo szybko narasta potrzeba czynnej i jednocześnie bezpiecznej turystyki. Nawet te pomniejsze pasma górskie, do jakich zaliczyć należy Sudety, mogły pochwalić się odpowiednio przygotowaną do oprowadzania grupą przewodników. Wspomniany już wcześniej amerykański turysta John Quincy Adams swoją niezbyt długą wyprawę po Śląsku wykorzystał, jak mógł najlepiej, wchodząc na Szczeliniec, Śnieżkę, oglądając wodospady Szklanki i Kamieńczyka. W jednym z listów do brata pisał:

Na wycieczki, jakie robiliśmy w tych górach, trzeba chodzić z przewodnikiem, znajomość wszystkich miejsc do zwiedzania, a do niektórych prowadzą ścieżki, jest rodzajem zawodu i jak w każdym zawodzie zawsze znajdzie się ktoś znakomitszy od innych. Tutaj najbardziej znanym przewodnikiem po Karkonoszach jest biedny szewc ze Szklarskiej Poręby Zygmunt Seidler, jun. Zöllner, który ogłosił w 1792 roku podróż na Śląsk odbytą rok wcześniej, umieścił tego niezmordowanego przewodnika, sławionego przez wszystkich niemieckich turystów, na pierwszym miejscu ${ }^{39}$.

Po raz drugi nazwisko Seidlera zostało zarekomendowane Adamsowi przez zaprzyjaźnionego frankfurckiego profesora, który nie tylko ręczył za jakość pracy owego przewodnika, ale wręcz nalegał na skorzystanie z jego usług nawet w przypadku, gdyby trzeba było czekać na jego dyspozycyjność, bo może być przeciążony zamówieniami aż do skutku. Ostatecznie Adams skorzystał z cennej podpowiedzi, wynajął protegowanego, by w jego towarzystwie wejść na Śnieżkę. Przebywając na szczycie, wolną chwilę postanowił wykorzystać nie tylko na kontemplację krajobrazu, ale i na towarzyską pogawędkę z przewodnikiem. Chciał dowiedzieć się czegoś o Liczyrzepie, legendarnym lokalnym duchu, który w wierzeniach tamtejszej ludności uchodził za postać wyjątkową: „Często ofiarował się jako przewodnik podróżnemu i zależnie od swojego widzimisię prowadził go uczciwie i na pożegnanie dawał piękne podarki, albo też wodził go na mokradła, albo w dziki gąszcz, potem wskakiwał na drzewo i wybuchał śmiechem ku przerażeniu swojej ofiary" ${ }^{\prime 40}$. Zagadnięty Seidler nie okazywał jednak wielkiej ochoty do podjęcia tematu Ducha Gór, wręcz poczuł się lekko urażony. Jego reakcja zaskoczyła Adamsa, który tak opisał zachowanie przewodnika:

Uważał, że kpię z niego, i powiedział, że nie tylko nikt go nie widział; ale też nigdy w niego nie wierzył, że Ślązacy nigdy nie wierzyli w bajki o nim, w które wierzą i rozpowszechniają tylko Czesi. Przypuszczam, że przewodnik czeski zapewniłby mnie, że to przesąd śląski, z którego jego współplemiennicy zawsze się śmiali ${ }^{41}$.

Ta przezabawna konwersacja wymownie świadczyła o sprycie i inteligencji przewodnika, który w oczach amerykańskiego turysty nie chciał uchodzić za czło-

\footnotetext{
39 J.Q. Adams, op. cit., s. 47.

40 Ibidem, s. 35.

${ }^{41}$ Ibidem, s. 57.
} 
wieka naiwnego i zabobonnego, a odcinając się od tego typu wierzeń i uciekając w zaprzaństwo, jawić się mógł jako ktoś bardzo postępowy. Jednocześnie, gdy po nocy przespanej w Budzie Hampla gospodyni obiektu ordynarnie potraktowała swoich gości, żądając lichwiarskiej opłaty, ów przewodnik, dla rozładowania nieprzyjemnej atmosfery, wytłumaczył to zachowanie wcześniejszym laniem, które sprawił jej mąż. Ile było prawdy w tej historii ułożonej na potrzebę chwili, a ile konfabulacji, tego Adams nie dowiedział się nigdy, ale ostatecznie przyjął taką interpretację nieprzyjemnego epizodu.

O historii rozwoju sudeckiego przewodnictwa wiemy dzięki poszukiwawczej pasji Ryszarda Kincla, któremu udało się spenetrować zachowane dokumenty archiwalne oraz ustalić pewne fakty, bardzo ważne dla historii śląskiej turystyki. Usługi przewodnickie, jeszcze niesformalizowane i o różnym stopniu profesjonalizmu, pojawiły się na tym terenie pod koniec XVIII wieku. Za pierwszego oficjalnego przewodnika uznaje się sołtysa i jednocześnie oberżystę z Karłowa Franza Pabla, który w 1813 roku otrzymał na to stanowisko urzędową nominację z rąk króla Fryderyka Wilhelma III (była to najprawdopodobniej pierwsza tego typu nominacja w Europie). Zasługą Pabla było dostosowanie Szczelińca do potrzeb ruchu turystycznego. Dzięki pobieranym opłatom za umożliwienie wejścia na szczyt i znajomościom w leśnictwie udało mu się zakupić materiał oraz zbudować drogę składającą się z 665 drewnianych stopni, która bezpiecznie doprowadzała na szczyt. Na wierzchołku góry wytoczył kilka ścieżek, nadał nazwy poszczególnym skałom, wyznaczył najlepszy punkt widokowy (prowadziły do niego oddzielne, dodatkowe schody), nazywając go Tronem Dziadka. Pabel przez dziesiątki lat osobiście wprowadzał turystów na szczyt Szczelińca, a zajęcie to dawało mu wiele satysfakcji i sprawiało przyjemność. Z wielkim oddaniem sprawie przekazywał informacje o samej górze i pobliskim Karłowie, a pasję swoją przekazał następnym pokoleniom.

Na sudeckich szlakach polscy przewodnicy pojawili się dość wcześnie, bo już w XVII wieku. Przywoływany Ryszard Kincel ustalił, że jednymi z pierwszych, a najprawdopodobniej pierwszymi polskimi przewodnikami byli Jerzy Fryderyk Suchodolski z Sosnówki i Jan Gruszczewski z Miłkowa. Suchodolski został wymieniony w pamiętnikach Krystiania Gotfryda Assmana podróżującego w 1788 roku, zaś Gruszczewski swój pobyt na Śnieżce upamiętnił wpisem w wyłożonej na szczycie księdze jako „krawiec meister ze Seydorf posłaniec z tej wsi roku 1812tego listopada"42. Gruszczewski pochodził z miejscowości dzisiaj noszącej nazwę Miłków. O sudeckich przewodnikach pisał także Marek Staffa w popularnej monografii Karkonosze. W formie ciekawostki napomykał o ich, mieszczących się w stylu ówczesnych zachowań, czynach, które dzisiaj są niedopuszczalne, takich, jak strącanie w dół kamieni, krzyki, strzały, zabijanie zwierząt na oczach turystów. Jednocześnie jednak podkreślał rangę przewodnickiego

42 Zob. R. Kincel, Początki przewodnictwa turystycznego w Karkonoszach, Jelenia Góra 1972, s. 21-25. Por. K.R. Mazurski, Historia turystyki sudeckiej, Kraków 2012. 
fachu, który wtedy cieszył się sporym poważaniem i przynosił stosunkowo dobry zarobek bardzo biednym mieszkańcom jego rejonu.

Zresztą przewodnictwem, noszeniem lektyk i bagażu zajmowała się najuboższa ludność wiejska — bezrolni lub małoletni chłopi i rzemieślnicy, którzy nie byli w stanie wyżyć z wyuczonego zawodu. Wobec rosnącego ruchu turystycznego i ostrej, nie zawsze uczciwej konkurencji ze strony przewodników, czasami niemających żadnych kwalifikacji, w wyniku czego zdarzało im się wodzić turystów po manowcach, zaszła konieczność urzędowego uregulowania tych sporów ${ }^{43}$.

Przełom XVIII i XIX wieku jeszcze bardziej obnażył dysfunkcyjność sudeckiej turystyki, ujawniając tym samym wiele nieprawidłowości, dominujący tam chaos i bałagan, co spowodowane było nie tylko złą organizacją pracy przewodników, ale także brakiem określonych standardów w poziomie świadczonych usług, wzajemne ,podprowadzanie” sobie klientów, czyli turystów, wewnętrzne personalne waśnie i spory. Narastające konflikty doprowadziły w ostateczności do tego, że ówczesny starosta jeleniogórski podjął pionierską pracę zmierzającą w kierunku prawnego uregulowania zasad funkcjonowania branży przewodnickiej. Odgórnie narzucono więc cennik na świadczone usługi, poczyniono pierwsze kroki w kierunku opracowania legitymacji zawodowych (sfinalizowano je w 1822 roku), określono wygląd obowiązującego przewodnika stroju (ubiór w kolorze zielonym, by współgrał z kolorystyką otoczenia, oraz nieodłączny filcowy kapelusz). W ten sposób ukonstytuowały się zręby organizacji nazwanej mianem Korpusu Przewodników Górskich, Tragarzy Lektyk i Bagaży, która była pierwszą tego typu instytucją w Europie i na całym świecie (podobną w Alpach datuje się na 1856 rok, w Tatrach — na 1875). Korpus dokonał hierarchizacji specjalizacji: od przewodnika, tragarza lektyk, po tragarza bagaży, a swoim zasięgiem objął Karpacz, Sobieszów, Sosnówkę, Piechowice i Szklarską Porębę. W 1824 roku dopracowano do końca status stowarzyszenia, uporządkowano i uszczegółowiono w zasadzie kompleksowo działalność przewodników i tragarzy, rozciągając opiekę korporacyjną na całe Karkonosze. Oficjalnie z organizacji tej wykluczeni byli Polacy, chociaż na ich, teraz już nielegalną, pracę przymykano oko ze względu na to, że większość objętych opieką członków korpusu nie potrafiła, z powodu bariery językowej, obsłużyć polskich turystów. Wymagania stawiane na ten czas przewodnikom karkonoskim były ściśle określone i dość wysokie, a regulacja obejmowała wszystkich bez wyjątku pracujących w tej branży. Przynależność do stowarzyszenia była obligatoryjna, ale żeby zostać członkiem i otrzymać legitymację, należało wcześniej uzyskać świadectwo moralności. Członkowie korpusu, w myśl obowiązującego regulaminu, mieli żyć ze sobą w zgodzie, zaprzestać rywalizacji o klientów, prawidłowo prowadzić rachunkowość itd. Dopiero pod koniec wieku (1885) udało się doprecyzować w szczegółach detale ubioru przewodnika górskiego. Strój ten składał się z brązowej lodenowej marynarki

${ }^{43}$ M. Staffa, Karkonosze, Wrocław 1996, s. 165-167. 
i spodni, podkolanówek, sznurowanych butów, ciemnozielonego pilśniowego kapelusza ozdobionego odznaką przewodnicką.

W 1850 roku na wrocławskim rynku wydawniczym pojawiła się niewielka, ale bardzo interesująca i ważna dla rozwoju polskiej turystyki publikacja Rozalii Saulsonowej zatytułowana Warmbrunn i okolice jego w 38 obrazkach zebranych przez Pielgrzymke w Sudetach. Był to pierwszy klasyczny przewodnik, który autorka zadedykowała podróżującym w te strony rodakom. Jego wartość poznawcza, próby waloryzacji górskiej przestrzeni, pragmatyczne wskazówki udzielone potencjalnemu turyście były na ten czas nie do przecenienia. Swoją podróż odbyła Saulsonowa w czasie, gdy na dobre działało już stowarzyszenie regulujące pracę przewodników, z których usług korzystała. Wszyscy turyści bardzo chętnie wynajmowali wtedy ludzi kompetentnych i odpowiednio przygotowanych do prowadzenia nawet krótkich wycieczek. Wybierającym się na Chojnik radziła na przykład Saulsonowa, aby swoją ekspedycję zaczynali od Sobieszowa, które było jedną z miejscowości, gdzie dokonywano werbunku przewodników: „Tam, jak w każdym godnym widzenia miejscu tych okolic, silny podróżny przewodnika, słabsi krzesła do niesienia ich przez dwóch tragarzy znajdują. Tym właściwa władza oznaczyła cenę, nad którą, z miejsca na miejsce, więcej brać nie mogą"44 — pouczała potencjalnych turystów. W podobny sposób sama wynajęła górala, w towarzystwie którego dotarła do Wodospadu Kamieńczyka: „Niestety utrudzającą drogą za przewodnika śladem idziemy w górę, dalej skaliste dzikie ustronie"45. Najmodniejsza, nieomal kultowa, wyprawa na Śnieżkę obowiązkowo musiała odbyć się pod fachowym okiem bardziej doświadczonych górali, chociażby $\mathrm{z}$ tego względu, że w pamięci ówczesnych żywe pozostawało wspomnienie tajemniczej śmierci samotnego turysty polskiego Józefa Odrowąża-Pieniążka, którego epitafium zawisło w kaplicy na Śnieżce.

Mniej więcej w podobnym czasie po Sudetach wędrował niestrudzony podróżnik Maciej Bogusz Stęczyński, a owocem tych wędrówek, właściwie ich pokłosiem, stały się dwa wzajemnie powiązane ze sobą poematy Śląsk i $S u$ dety wzbogacone o bardzo ciekawą szatę ilustracyjną. W rękopisie pierwszego $\mathrm{z}$ wymienionych utworów zawarł autor $\mathrm{w}$ formie przypisu godną uwagi informację, nader istotną dla badaczy historii karkonoskiej turystyki. Otóż odnotował Stęczyński nazwisko przewodnika, z usług którego korzystał, a brzmiało ono Walenty Grzała. Był to najprawdopodobniej jeden z nielicznych polskich przewodników, którzy nieformalnie (ze względu na narodowość nie mógł należeć do pruskiego stowarzyszenia) oprowadzali turystów — rodaków. Owego sudeckiego górala wykreował Stęczyński na człowieka operującego szeroką i rozległą wiedzą z zakresu topografii, etnologii, kultury, a nawet onomastyki. Przewodnik, wprowadzając turystę w granice „Kamiennego Miasta”, bo takim mianem zwykło określać się Aderspach (Adršpach), zasypywał go informacjami świadczącymi

${ }^{44}$ R. Saulsonowa, Warmbrunn i okolice jego w 38 obrazach zebranych w 12 wycieczkach przez Pielgrzymkę w Sudetach, oprac. P. Cimicki, Wrocław 2004, s. 22.

45 Ibidem, s. 29. 
o dobrej znajomości szczegółów wyznaczających tę przestrzeń, na którą w większości składały się olbrzymiej wielkości, przebogate w formie, głazy narzutowe. Rozbudzały one ludzką wyobraźnię do tego stopnia, że tym wyjątkowym wytworom natury ponadawano spersonalizowane nazwy:

A przewodnik dokładnie każdą pokazuje

I w każdej podobieństwo dziwaczne znajduje:

Kapucyn, Sędzia, Urna, Ząb, Grzyb, Szubienica,

Kotły, Zwaliska Zamku, Mops i Zakonnica,

Kopa Płótna, Lwia Głowa ${ }^{46}$.

Z kolei na szczycie Śnieżki przewodnik, realizując romantyczne przesłanie „Tam sięgaj, gdzie wzrok nie sięga”, usiłował wzrokiem wybiec poza linię horyzontu, odwołując się do imaginacji i wyobraźni turysty. Ta swoista lekcja geografii, swoimi antecendencjami sięgająca do Staszica, była w ówczesnej konwencji poetyckiej stosowana niejednokrotnie, co związane było z charakterystyczną dla tej epoki reakcją na walory pejzażu ${ }^{47}$. Stąd nie powinno dziwić to, że turyście pokazywano ze szczytu takie elementy krajobrazu, które były realnie niemożliwe do zobaczenia:

Przewodnik pokazuje rozmaite grody,

Miasta, włości, kopalnie, mineralne wody;

Pokazuje, gdzie Berno, a gdzie Wiedeń leży,

Gdzie Kraków i Warszawa ${ }^{48}$.

Wykreowany na potrzeby romantycznego poematu opisowego wzorcowy model przewodnika najprawdopodobniej miał nieśmiałego swojego protoplastę w osobie wspomnianego Grzały. W poemacie Śląsk natrafić można jednak było także na niezmiernie interesujący przypis, który dotyczył nazwy jednej z górskich rzeczek z następującym odautorskim komentarzem: „Mój przewodnik Walenty Grzała mówił mi, że to Wrzączka, potem słyszałem, że to Mrukla [...]. Bo co inna okolica, inny służył nam przewodnik, a nie zawsze trafić można na człowieka świadomego"49. Przytoczona uwaga wskazywała na to, że występująca w obu poematach Stęczyńskiego postać sudeckiego górala była kreacją literacką wystylizowaną na potrzeby gatunku, choć proweniencją sięgającą do prawdziwych, realnych przewodników, z którymi na szlaku obcował autor. Ten świadomy zamysł artystyczny umożliwiał wykreowanie idealnego przewodnika

46 B.Z. Stęczyński, Sudety jako dalszy ciag poematu Tatry, oprac. J. Kolbuszewski, Jelenia Góra 1981, s. 48.

${ }^{47}$ Zob. E. Kolbuszewska, Romantyczne przeżywanie przyrody. Znaczenie wartości, style zachowań, Wrocław 2007, tu: Romantyczne przeżycie szczytu, s. 35-73; eadem, Szczyt górski jako miejsce transgresji. Wersja romantyczna, „Góry - Literatura - Kultura” 2017, nr 11, s. 57-68.

48 B.Z. Stęczyński, op. cit., s. 67.

49 B.Z. Stęczyński, Śląsk. Podróż malownicza w 25ciu pieśniach [rękopis w zbiorach ZNiO we Wrocławiu sygn. 3424/1, 1850], s. 58. 
świetnie odpowiadającego zapotrzebowaniu romantycznego poety. Możemy więc w tym przypadku śmiało mówić o hiperbolizacji tej postaci i przypisaniu mu znaczniejszej roli, niż prawdopodobnie odegrał w rzeczywistości w procesie poznawania sudeckich walorów górskich. Prowadzony przez Stęczyńskiego tok narracji nasuwa przypuszczenie, że ów przewodnik to w pewnym stopniu alter ego samego poety. Wskazuje na to sposób widzenia i opisu świata, wyjątkowa skala wrażliwości, momentami przechodzącej w egzaltację, duża wiedza, dar oratorski, mentorskie usposobienie. Przy Czarnym Stawie odwołał się przewodnik do legendy o Duchu Gór, czyli Liczyrzepie, co dla romantycznego turysty będącego żywo zainteresowanym demonologią ludową musiało być sporą atrakcją. Swój monolog spointował radą, która nie mogła zdziwić czytelników Mickiewicza i mieściła się w konwencji epoki:

Abyśmy czystą myślą tchnęli tu koniecznie,

I mieli szczerość w sercu, pogodę na czle,

A ten duch nie wyrządzi nam żadną swawolę ${ }^{50}$.

Te słowa, z jednej strony, wskazywały na naturalną bojaźń i lęk przed owianym złą sławą Liczyrzepą, z drugiej zaś - świadczyć mogły o umiejętnym operowaniu elementem grozy, których oczekiwali ówcześni turyści. Z kolei doprowadzając do dużej skały z charakterystycznymi po procesie wietrzenia wgłębieniami, uraczył towarzystwo opowieścią o zwyczajach, religijnych obrzędach dawnych mieszkańców gór, dla których owo miejsce miało magiczne i kultowe znaczenie. Momentami jego wypowiedzi, przemyślane i wyważone, przepełnione były myśleniem proekologicznym podbudowanym świadomością estetyki oglądanego krajobrazu. Góry i ich najbliższe otoczenie, a więc to, co znajduje się w spektrum uwagi turysty, były dla przewodnika kwintesencją prawdziwego piękna, ostoją tego, co dla człowieka dobre. Stąd płynęła świadoma waloryzacja przestrzeni:

[...] - a góral wyrzeka:

A co! Wszakże mówiłem, że te góry, lasy,

Te przepaści, doliny, trawy jak atłasy; [...]

Są prześliczne, wszak prawda? ${ }^{51}$

Jednocześnie, wychodząc naprzeciw szerszym zainteresowaniom słuchaczy, dokonał przewodnik ciekawej egzegezy krajobrazu Gór Izerskich. Z estetycznego punktu widzenia były one dla niego obce i dzikie, zbyt pospolite, obrośnięte puszczą, pozbawione naturalnych osobliwości, a tym bardziej malowniczości. Dyskredytował ich wartość estetyczną w sposób dość bezwzględny, uważając, że dla malarzy są bezwartościowe, dla turystów — niegościnne, ale jednocześnie posiadają — co uczciwie podkreślił — ogromny potencjał geologiczny (cenne kamienie, żyłki złota). Te wypowiadane wielokrotnie w tonie mentorsko-dydaktycznym wstawki oratorskie nie przeszkadzały i nie uniemożliwiały sprawnym kierowaniem całością

50 B.Z. Stęczyński, Sudety..., s. 77.

51 Ibidem, s. 147. 
wyprawy. To przewodnik wyznaczał punkty widokowe, miejsca postoju i biwaku, elastycznie dysponował czasem przemarszu. I tak na przykład: „Posłuszni jego radzie idziemy zmuszeni'"52, lub:

A przewodnik do góry szybko postępuje,

Ogląda się: prosi - nawet rozkazuje

Spinać się coraz wyżej, pomimo spocenia,

By na wierzchołku użyć wypocznienia ${ }^{53}$.

Ten włożony trud i wysiłek ostatecznie docenił Stęczyński, opisując pracę przewodnika prostymi ciepłymi słowami, które odebrać można jako formę poetyckiej podzięki:

Rozmaitym kierunkiem góral postępuje,

Albo co opowiada, albo pokazuje;

Umie gościa swojego bez przerwy zajmować

Aby na utrudzenie nie mógł utyskować ${ }^{54}$.

W 1876 roku w jednym z najpoważniejszych polskich czasopism tematycznie związanych z górami pojawiła się krótka informacja dotycząca powstania pierwszego francuskiego klubu alpejskiego. Jej autor - Władysław Koziebrodzki - w ostrych słowach skrytykował Francuzów za to, że dotychczas nie potrafili wypracować zamiłowania do gór, pierwotnej dzikiej przyrody, czyli jednym słowem - nie docenili walorów płynących z uprawiania i popularyzowania turystyki. W konsekwencji braku ambicji, żyłki sportowej do tego, by podbijać dziewicze tereny górskie, dali się na tym polu zdominować Anglikom, Niemcom czy Włochom anektującym europejską turystykę. Jednocześnie przypomniał Koziebrodzki, że Francja, choć posiada prawnie najwyższe szczyty w łańcuchu Alp, a ponadto część Pirenejów z pasmami Jury, Wogezów czy Mont-Dore, nie przyczyniła się $\mathrm{w}$ najmniejszym stopniu do wykreowania mody na uprawianie turystyki górskiej. Przez takie mniej lub bardziej świadome zaniechanie ogół mieszkańców tego kraju „nie rozbudził w sobie zapału do tego świata, o którego cudach mówili jego przyrodnicy, uczeni, malarze i poeci" 55 . Kolejny zarzut autora artykułu dotyczył nieprzystosowania tamtejszych terenów górskich do celów turystycznych. $Z$ ubolewaniem Koziebrodzki wymieniał listę niedociągnięć: braki cywilizacyjne, ogólne zacofanie, niski poziom życia mieszkańców. Zamieszkujący te tereny pasterze żyli nieomal w nędzy, a nie posiadając nadwyżek żywności, nie handlowali jedzeniem. Do problemów aprowizacyjnych dochodziły socjalno-bytowe (prymitywne gospody, powszechny bród połączony z brakiem higieny itd.). Stąd pionierskie ekspedycje w Pireneje do najłatwiejszych nie

52 Ibidem, s. 80.

53 Ibidem, s. 147.

54 Ibidem, s. 114.

55 W. Koziebrodzki, Pierwszy rocznik Klubu Alpejskiego Francuskiego, „Pamiętnik Towarzystwa Tatrzańskiego" 1876, nr 1, s. 89. 
należały, o czym miał się przekonać jeden z odważnych prekursorów turystyki: „Nigdzie schronisk, przewodnicy niedoświadczeni, mapy niedokładne, słowem: musiał wszystko sam stworzyć i sam na sobie polegać" 56 . Zadufani w sobie i bezkrytyczni Polacy, zarzucając Francuzom opieszałość, ociężałość w poszukiwaniu głębokich i silnych wrażeń na niebotycznych szczytach, zapominali, że sami pozostawali w znacznym opóźnieniu w penetracji rodzimych gór. Ówczesna znajomość długiego dość łańcucha Karpat ograniczała się w rzeczywistości do Tatr, Pienin i kawałka bardziej ucywilizowanej Czarnohory. Pozostała ogromna część owych gór była terra incognita, jeszcze bardzo długo turystycznie odrzucana i zaniedbana. Obszar ten w świadomości turystów jawił się dość ponuro jako dziki, niedostępny, słabo zaludniony i podobnie jak Pireneje rzeczywiście pozbawiony odpowiedniej infrastruktury umożliwiającej głębszą jego eksplorację. To wszystko było prawdą, ale jednocześnie nie oznaczało zupełnego wykluczenia tej części Karpat z map turystycznych. Podróżowanie w te góry wymagało jednak samozaparcia, dobrej woli i umiejętności przystosowania się do prymitywnych warunków bytowych. Jednym słowem - trzeba było zaprezentować postawę ekstrawersyjną odznaczającą się ogólną zaradnością połączoną ze wzmożoną aktywnością. We własnym zakresie turysta zorganizować i zapewnić musiał sobie prawie wszystko, czyli miejsce noclegowe, wyżywienie i opiekę przewodnika. O tych problemach, na które natrafiali podróżujący, pisał znawca Huculszczyzny:

Zasadniczą trudnością w uprawianiu turystyki w Karpatach Wschodnich był początkowo brak jakiejkolwiek infrastruktury i informacji, a także „zawodowych” przewodników huculskich, co pobyt w Huculszczyźnie czyniło nader romantycznym, lecz mocno ryzykownym ${ }^{57}$.

Znawców topografii terenu szukano po omacku, w ciemno, uruchamiając system prywatnych znajomości i protekcji. Brak profesjonalnych przewodników doprowadzał do tego, że wynajmowano do oprowadzania ludzi przypadkowych, polecanych najczęściej przez leśniczych czy właścicieli majątków. Potwierdzał ten fakt Józef Dziędzielewicz, który w latach osiemdziesiątych XIX wieku odbył ekspedycję w głąb Karpat: „Huculi nie przywykli do częstych nawiedzań przez turystów, nie trudnią się przewodnictwem: nie ma tu więc przewodników z zawodu"58. Dodatkową trudność dla turystów stanowiło spore oddalenie od siebie stanowisk pasterskich, osiedli i miejsc biwakowych tamtejszych górali. Wyprawy planowane były na kilka lub kilkanaście dni, co dawało możliwość bliższego poznania życia oraz kultury huculskiej i sprzyjało nawiązaniu z Hucułami bliższego kontaktu. Łącznikiem pomiędzy nieufnymi góralami a przyjeżdżającymi w Karpaty turystami był przewodnik, tubylec, mniej lub bardziej obeznany z tamtejszą topografią, ale wywodzący się z huculskiego środowiska. W 1876 roku na

56 Ibidem, s. 90.

57 J.A. Choroszy, Huculszczyzna w literaturze polskiej, Wrocław 1991, s. 105.

58 J. Dziędzielewicz, Wycieczki po wschodnich Karpatach, „Pamiętnik Towarzystwa Tatrzańskiego" 1877 , nr 2, s. 41. 
wycieczkę po Czarnohorze wybrał się Włodzimierz Hankiewicz, a towarzyszyło mu dwóch przewodników. Już na samym początku ekspedycji turysta emocjonalnie zareagował na widok wyłaniającej się góry kształtem przypominającej głowę cukru. Pragmatyczny góral szybko okiełznał ów zachwyt, przynaglając do szybszego marszu: „Toż to Howerla, najwyższy szczyt Czarnogóry — rzecze przewodnik - pod jej szczytem dziś nam nocować, a pana jak gdyby do miejsca przykuł. Spieszmy, bo droga daleka, a widoki piękniejsze. Usłuchałem go więc i ruszyłem dalej" 59 — pisał Hankiewicz. Na samym szczycie góral, dobrze już obznajomiony i oswojony z turystą, opowiedział krążącą po tych terenach legendę o zbójniku Doboszu. Hankiewicz, wcześniej podróżując po innych górskich regionach, ludowy przekaz skomentował słowami: „Legendę tę całkiem podobnej treści, a odmienną tylko co do miejsc, słyszałem nieraz od Bojków w górach Samborskich" 60 , co świadczyć miało o żywotności tego typu ustnych przekazów i wspólnocie kultury góralskiej, którą wiek XIX uszanował, oraz bardzo ceniąc, chciał bliżej poznać. Mniej więcej w tym samym czasie (1879) w kierunku Bukurty i czarnohorskich jezior podjął ekspedycję Leopold Wajgiel (przyrodnik, etnograf), wędrując w towarzystwie dwóch przewodników: Hucuła leśnego i Ormianina. Naukowiec podczas trwania wyprawy zatknął się także z opowieściami o poczynaniach Dobosza, a że legenda wśród Hucułów była nadal żywa, powoływali się oni na nijakiego Hrycia Popieluka, kompana opryszka, który jeszcze wtedy ponoć żył, choć liczyć miał 115 lat. Znacznie większe wrażenie zrobił jednak na Wajglu, zajmującym się także antropologią, zabobonny strach górali, który ujawnił się w momencie najmniej spodziewanym, bo u brzegów jeziora Dancerz. Według ludowych wierzeń w jego wodach zamieszkiwać miały złe duchy, które topiły zbłąkane bydło. By ich nie prowokować, zabronione było wrzucanie w jego odmęty kamieni, gdyż to miało w konsekwencji grozić burzą i gradobiciem.

Huculi tak są przekonani, że wszelkie namowy z mej strony, ażeby przewodnicy udali się ze mną do tego jeziora, były nadaremne, aż wreszcie jeden ujrzawszy mnie mierzącego to jezioro bezkarnie, zeszedł na dół, a drugi z końmi pozostał na górze, przypatrując się ciekawie, czy „ozero" to się nie zagniewa; a jakież było zdziwienie oby, gdym w oczach ich rzucił raz i drugi kamień do wody, nie wywoławszy burzy! ${ }^{61}$

Zapewne moment konfrontacji polegającej na zdemontowaniu utrwalonego w świadomości przewodników ludowego przesądu nie zamknął całej sprawy do końca, ale mógł w znacznym stopniu złagodzić u przewodników ich niezdrową ekscytację oraz oswoić wielki lęk. Także w latach osiemdziesiątych do Czarnohory udał się Hugo Zapałowicz w towarzystwie Teodora Pareńskiego i górala z Zawoi

59 W. Hankiewicz, Wycieczka na Czarnohorę, „Pamiętnik Towarzystwa Tatrzańskiego” 1879, nr 4, s. 38.

60 Ibidem, s. 43.

${ }^{61}$ L. Wajgiel, O Burkucie i jeziorach czarnohorskich (opis wycieczki odbytej w 1879), „Pamiętnik Towarzystwa Tatrzańskiego" 1880, nr 5, s. 70. 
- Wawrzyńca Szkolnika, którego znał z poprzednich eskapad. Wyprawa miała charakter naukowy, konkretnie — botaniczny, i przewidziana była na kilka tygodni. Jako przewodnika zatrudniono tubylca, Rusina, o którym Zapałowicz pisał:

Iwan Żyteniuk, nasz przewodnik po Czarnohorze, był mężczyzną rosłym, silnym, choć już na schyłku wieku męskiego, miał rysy twarzy ostre i podłużne i długie czarne włosy. Dawniej zamożny gospodarz w Żabiu, wskutek nieszczęsnego zamiłowania do wódki począł gospodarstwa zaniedbywać, trwonić, aż mu ją Żydzi w całości zabrali [...]. Przez długie lata owczarzył po Czarnohorze, stąd ją też zna całkowicie ${ }^{62}$.

Miejscem zakwaterowania i jednocześnie bazą wyprawy stała się jedna z chat przysiółka znacznie oddalonego od Żabiego, pozbawionego drogi i odciętego od cywilizacji. Wyżywienie turystów było nader skromne, a składało się na nie nabiał, kawa, ryż i chleb. O mięsie można było zapomnieć, ale te wszelkie niedogodności rekompensowała bliskość oraz dostępność gór. Towarzyszący Wawrzyniec Szkolnik, polski góral, dał się poznać naukowcom jako człowiek pracowity, sumienny, doświadczony i obeznany z górską przestrzenią. Rusin Iwan był z kolei dla zżytego ze sobą zespołu zupełnie obcy i dopiero w trakcie trwania ekspedycji na jaw wyszły, $z$ jednej strony, niedostatki jego charakteru, z drugiej zaś - dobrze wyrobiony zmysł przewodnicki. Uparty, niecierpliwy, początkowo nie mógł zrozumieć istoty i charakteru pracy naukowców, przez co sprawiał im liczne problemy. Niełatwą współpracę z Rusinem opisywał Zapałowicz: „Gdyśmy mu bowiem oświadczyli, że chcemy, aby nas np. wyprowadził potokiem do góry, albo zawiódł na jakieś skały z boku, odpowiadał: »A na szoby ja tam pusto chodył«, nie mogąc pojąć, dlaczego wybieramy gorszą drogę"63. Dodatkową przeszkodą $\mathrm{w}$ bliższych interakcjach $\mathrm{z}$ przewodnikiem stanowiła bariera językowa, a pierwsze kroki zmierzające do opanowania języka ruskiego poczynił Wawrzyniec: „Pomagał sobie jednak, jak mógł, kalecząc w okropny sposób język ruski. Sądził także zarazu, że im więcej przekręci słowa polskie, tym się zrozumialszym stanie Rusinowi i pękaliśmy nieraz ze śmiechu, słysząc go rozmawiającego z Rusinami mową, którą właściwie on sam tylko rozumiał"64. Wawrzyniec dość szybko wyuczył się słów, które były niezbędne do podstawowej komunikacji, i stał się naturalnym pomostem pomiędzy naukowcami a krnąbrnym i upartym Rusinem, który w miarę upływu czasu zyskiwał coraz większą ich sympatię. Iwan, jako reprezentant rdzennych mieszkańców tego regionu, stawał się naturalnym obiektem obserwacji antropologiczno-kulturowej. Imponował znakomitą grą na piszczałkach i umilał czas, wygrywając na nich rzewne, tęskne ruskie dumki. Na planowaną dłuższą wyprawę w góry przybył zaopatrzony w biesiagi, czyli coś, co przypominało dwa zszyte ze sobą w górnych częściach

62 H. Zapałowicz, Z Czarnohory do Alp Rodneńskich, „Pamiętnik Towarzystwa Tatrzańskiego" 1881, nr 6, s. 24-25.

63 Ibidem, s. 29.

64 Ibidem. 
brzegów worki, zrobione przez Hucułów z wełny. Biesiagi przewieszał sobie na ramieniu w ten sposób, że jeden $\mathrm{z}$ worków zwisał mu na piersiach, a drugi leżał na plecach. Obciążony sporym bagażem miał jednocześnie zapewnioną całkowitą swobodę ruchów ciała. Iwan pozornie był człowiekiem szorstkim i twardym, pozbawionym wrażliwości, ale na widok miejsc związanych ze wspomnieniami przeszłości zachowywał się bardzo emocjonalnie, z ogromnym sentymentem, co ze zdumieniem zauważyli jego towarzysze:

Zdziwiło nas to jego rozrzewnienie i uczuliśmy głębsze dla niego współczucie. Myśmy go bowiem dotąd znali raczej jako człowieka szorstkiego, a ta strona uczuciowa objawiła się w nim przed nami po raz pierwszy teraz dopiero. Jego bezwzględne postępowanie i brak tej troskliwości o resztę towarzystwa [...] nieraz nas już niecierpliwiły. Mimo to odstępowaliśmy jednak zawsze od zamiaru poszukiwania sobie innego przewodnika, gdyż znał wybornie Czarnohorę i miał wielki zmysł w orientowaniu się. Usprawiedliwialiśmy zresztą jego postępowanie także i tym, że nie przewodniczył dotąd jeszcze nigdy żadnym innym turystom ${ }^{65}$.

Świadczyły te słowa o tolerancji i dużym kredycie zaufania, który udzielono Iwanowi. Zresztą w miarę upływu czasu zyskiwał on sympatię, bo z coraz większą starannością wypełniał swoje obowiązki przewodnickie. W momencie, gdy wyprawa skierowała się w rejony mniej mu znane, potrafił nie tylko wypytać się o dobry kierunek, ale także zapamiętać — jak pisał Zapałowicz — „takie przedmioty orientowania się, że nas to przekonało, iż on z całkiem innego punktu widzenia stara się zasięgnąc języka o okolicy nieznanej”"66. Decydując się na penetrację Alp Rodniańskich (leżących na granicy Siedmiogrodu i Węgier), należało liczyć się z dodatkowymi nieprzewidzianymi wypadkami, albowiem okolice góry Pietros nie były dla turystów ani przyjazne, ani bezpieczne. Pociągały jednak one swoją niedostępnością i pięknymi widokami. Głównie uwagę w krajobrazie przyciągała niesamowita skalna formacja, jaką był ów różnie nazywany Pietros (Pietrus, Pietrosz). Bystry Iwan, wskazując na wyodrębniający się szczyt, a chcąc podzielić się tą uwagę $\mathrm{z}$ naukowcami, zastosował swoistą grę ciała połączoną $\mathrm{z}$ mimiką, przełamując $\mathrm{w}$ ten sposób barierę językową:

Mówiąc to, objaśniał nas dla większej dokładności ruchami, które palcami wykonywał. I jak mowa jego była dziwacznie cichą, tak i ruchy rąk były drobne, niemal dziecinne, i chociaż trafnie rzecz naśladowały, nie zdawały się na pozór pozostawać w żadnym związku z tą jego zamaszystą postacią i z tym olbrzymem Pietrosu, którego właśnie opisywał ${ }^{67}$.

Na granicy Alp Rodniańskich kończyła się jednak jego znajomość topografii terenu i nastąpiła konieczność zatrudnienia dodatkowego przewodnika. Po noc-

\footnotetext{
65 Ibidem, s. 39.

${ }^{66}$ Ibidem, s. 41.

67 Ibidem, s. 47.
} 
legu w Bursie, idąc za poradą tamtejszego kowala, zdecydowano się wynająć zaprotegowanego Cygana. Twierdził on bowiem, że w okolicy zamieszkuje wielu Rumunów, którzy dobrze poruszają się po tym terenie, ale ze względów czysto pragmatycznych (nieznajomość języka rumuńskiego) najlepiej do tego celu nadawał się polecony Cygan, który władał trzema językami: ruskim, rumuńskim i węgierskim, znał drogę na szczyt i był odpowiedzialnym człowiekiem. Przy takiej rekomendacji zatrudnienie tej poleconej osoby stało się już tylko czystą formalnością. Cygan przybył na miejsce zbiórki ze sporym opóźnieniem, a odziany był w strój, który w znacznym stopniu odbiegał od ubioru noszonego w tamtejszym regionie. Kostyn, bo tak brzmiało jego imię, na nogach miał kierpce i ubrany był w letnie szarawary, białą zniszczoną i połataną guńkę, na głowę założył stary węgierski kapelusz, a przez ramię przewiesił torbę. Już na wstępie zapewnił, że dobrze zna tutejsze góry i potrafi uczynić zadość oczekiwaniom turystów. Z lekkim rozbawieniem opisywał Zapałowicz: „Cygan szedł na czele, krokiem lekkim i cokolwiek tańczącym, z miną pyszną, jakby chciał mówić: chodźcie, patrzcie się na mnie, jak ja to prowadzę panów przybyłych gdzieś z dalekich stron! Lecz i bez tego wezwania prześladowała nas zewsząd ciekawość i natręctwo"68. Bardzo szybko okazało się, że Kostynowi nie brakuje tupetu, ale doświadczenia i orientacji w terenie już tak. Prowadził wyprawę bez szczególnego przekonania co do prawidłowości obranego kierunku. W miarę upływu czasu zaufanie w jego „sztukę przewodniczenia" coraz bardziej malało, a pojawiać zaczęło się przeczucie nieufności i niepewności. Dyletanctwo Cygana obecne było na każdym kroku. Gdy zespół forsować zaczął wierzchołek Pietrasa, Kostyn sprawiał wrażenie, jakby tę górską grań ,po raz pierwszy oglądał, zapytany, którędy nas na szczyt poprowadzi, podniósł rękę w stronę szczytu, czyniąc jakiś ruch niewyraźny"69. W charakterze Cygana górę brały niefrasobliwość i niesubordynacja, co często stawało się w zespole przyczyną spięć oraz sytuacji konfliktowych. To stłukł jedyny garnek przeznaczony do gotowania wody, to zabrakło mu pożywienia (każdy uczestnik wyprawy posiadał swój prowiant) i wypadało się z nim podzielić, lub źle przygotował miejsce biwakowe, mylił drogi itd. Czasami jednak, choć raczej rzadko, przypominał sobie o funkcji, jaką miał pełnić, i zadaniach, których się podjął. I tak na przykład w momencie schodzenia w dół leśną ścieżką

wysunął się naprzód. Lecz przeznaczone mu było jeszcze raz pobłądzić, wskutek czego wpędziliśmy się w wyłomy. Tym razem przebrała się nam już miarka cierpliwości i złajaliśmy Cygana, jak on śmie się do przewodniczenia porywać, nie znając nawet drogi ze stacji do Borsy. Cygan wymawiał się, że wyłomy musiały niedawno ścieżkę zawalić, lecz już nie puszczaliśmy go naprzód ${ }^{70}$.

68 Ibidem, s. 50.

69 Ibidem, s. 53.

70 Ibidem, s. 67. 
Takie postępowanie nie było w żadnym przypadku spowodowane wyraźnie złą wolą Cygana, ale upewniało ono w przekonaniu, że to nie przewodnik, a dyletant i mały hochsztapler, który nigdy nie brał udziału w dłuższych wyprawach górskich. Istniało spore prawdopodobieństwo, że mógł prowadzić czasami jednodniowe wycieczki, ale na tym kończyło się jego przewodnickie doświadczenie. Oszustwo na nic się nie zdało, bo charakter ekspedycji przerósł jego możliwości, a przeżyte podczas wyprawy wypadki powinny być dla niego nauczką i lekcją pokory. Na tle indolencji Cygana zupełnie inaczej zaczęła rysować się sylwetka i miejsce oraz pozycja Iwana. Porywczy, pewny swoich racji i często niepotrafiący żyć w konsolidacji z innymi Rusin przewyższał go nie tylko doświadczeniem, ale także zmysłem orientacji, spostrzegawczością i łatwością orientowania się w terenie. Na górskich szlakach, kierując się zdrowym rozsądkiem i rozwagą, potrafił zablokować pochopne decyzje naukowców. Jednocześnie posiadał Iwan coś takiego, co można by nazwać szóstym zmysłem, instynktem przewodnickim, gdyż świetnie potrafił poruszać się w terenie wcześniej sobie nieznanym. Podczas trwania wyprawy zdarzały się u niego momenty niepewności, zawahania, ale zawsze jego wybór był optymalny. W trakcie jednej z eskapad zaistniało prawdopodobieństwo pomyłki wyboru drogi, ale powód niepokoju Iwana okazał się bardzo prozaiczny: „On tylko nie wiedział, że przeszłej jesieni lasy, które tu zrąbano, zawaliły tę ścieżkę. Poszedł na zwiady, lecz wkrótce wrócił i poprowadził dalej, omijając wyręby na prawo"71. Innym przykładem świadczącym o inteligencji Iwana był moment powrotu, w strugach ulewnego deszczu, ze szczytu Butryńca. Niesprzyjające warunki pogodowe wymagały szczególnej roztropności, ostrożności i wielkiej koncentracji, o czym dobrze wiedzieli przemoczeni do szpiku kości uczestnicy wyprawy. Powrót ten opisał Zapałowicz:

Odtąd postępowaliśmy wciąż grzbietem, prawie się nic nie zniżając ani podwyższając, wśród gęstej mgły i ciągłego deszczu. Iwan szedł naprzód, my w milczeniu postępowaliśmy za nim. Co chwilę zmienialiśmy kierunek, lecz w którą stronę świata podążaliśmy za każdą zmianą kierunku, lub gdzie się w ogóle znajdowaliśmy, o tym snuły się nam tylko domysły po głowie. Tylko Iwan wiedział dokładnie, gdzie się znajdujemy ${ }^{72}$.

$\mathrm{W}$ rozbudowanym przypisie kończącym artykuł usiłował Zapałowicz uzasadnić dokonany przez siebie wybór formy literackiej, jaki przyjął w celu najlepszego i najdokładniejszego przedstawienia przebiegu kilkudniowej ekspedycji naukowej. Celem nadrzędnym tej wyprawy było botanizowanie, zebranie i opis jak największej ilości obrazów górskiej flory, ale jednocześnie, gdzieś obok, zrodził się pomysł upamiętnienia w epickiej narracji przebiegu owej wycieczki. Autor, wybierając formę rozbudowanego opowiadania, usprawiedliwiał się przed potencjalnym czytelnikiem z marginesowego potraktowania „treści więcej społecznej natury", chociaż zamieszczony w zakończeniu przypis był raczej

\footnotetext{
71 Ibidem, s. 74.

72 Ibidem, s. 81.
} 
wyrazem jego nadmiernej skromności i zbytniego krytycyzmu. Udało się bowiem Zapałowiczowi oddać zarówno specyfikę huculskiej kultury, jak i nakreślić psychologiczne portrety ludzi, z którymi wędrował. Przedstawiając ich słabości, śmiesznostki, równoważył je $\mathrm{z}$ walorami, talentami czy poczuciem humoru, którymi byli obdarzeni. Zestawiając ze sobą przedstawicieli trzech odmiennych kultur reprezentowanych przez górala z Zawoi, huculskiego Rusina i Cygana, nakreślił sympatyczny obraz nieprofesjonalnych przewodników, którzy diametralnie inaczej postrzegali otaczający ich świat i swoje obowiązki, a spotkali się przypadkiem na górskich szlakach.

W 1881 roku Góry Sołotwińskie należące do Karpat Wschodnich w wąskim gronie przyjaciół postanowił zwiedzić Emeryk Turczyński. Ciągnęła go w te strony, na szczyt Sywuli i Wysokiej, wielka ciekawość połączona ze świadomością, że tereny te są zupełnie omijane: „Żałować należy, że te tak piękne góry mało bywają przez turystów i badaczy zwiedzane"73. Młodzi zdecydowali się na wycieczkę całkowicie improwizowaną, bez sztywnego programu, wcześniejszych przygotowań i „,bez żadnych tak na miejscu jak po drodze ułatwień”. Na początku pierwszym bojowym zadaniem stało się wyszukanie przewodnika dobrze obeznanego z terenem, co wcale nie było łatwą sprawą. Do tego dochodziły kłopoty z kwaterunkiem. Potencjalnym przyszłym turystom przekazywał Turczyński nabywane wraz z upływem czasu swoje bezcenne rady, pisząc, że „w celu wyszukania dobrego przewodnika i pomocników do noszenia pakunków i żywności trzeba udać się do pana rządcy i tylko poleconych przezeń ugodzić, aby później nie doznać nieprzyjemności i zawodów. Lud bowiem tutejszy bardzo zepsuty, przy tym chwiejny i nieporadny"74. W opinii ówcześnie podróżujących po Karpatach rdzenni ich mieszkańcy, Huculi, nie należeli do przebojowej i znaczącej grupy etnicznej. Charakteryzował ich łagodny charakter, widoczny brak zdecydowania, który uniemożliwiał uzgodnienie warunków pracy. Pisał Turczyński o tych trudnościach: „To też z żadnym przewodnikiem nie łatwo się nam było zgodzić, gdyż nie wiedział, czy ma iść, co żądać, czy to dość, czy za mało?"75. Jednocześnie przy turystach kręcił się nieznajomy człowiek o imieniu Stefan, który podawał się za osobę kompetentną, ale nie wzbudzał zaufania i istniało podejrzenie, że jego znajomość drogi stoi pod dużym znakiem zapytania. Ostatecznie skorzystano z pomocy rządcy dóbr, który na przewodnika polecił jednego ze swoich pracowników, jednocześnie obligując się do wyznaczenia dodatkowego „dokładnie z dalszą drogą obznajomionego”. W takich okolicznościach można było rozpocząć eskapadę. Część niezbędnych pakunków niósł koń, część —ów Stefan, który nie odpuścił w swoich staraniach o zatrudnienie. Początkowo zaaprobował on warunki umowy, ale gdy zobaczył, że główny przewodnik dostaje wyższe uposażenie, zaczął domagać się podwyżki, co świadczyć miało o jego

73 E. Turczyński, Wycieczka na Sywulę $i$ Wysoka, „Pamiętnik Towarzystwa Tatrzańskiego” 1883, nr 8, s. 137.

74 Ibidem, s. 138.

75 Ibidem, s. 139. 
cwaniactwie. Zatrudnieni górale początkowo w miarę dobrze i sprawnie wypełniali swoje obowiązki, ale brakowało im kompetencji geograficznych. Zirytowany Turczyński konstatował, że niezupełnie na przykład udało się zidentyfikować połoninę oznakowaną na mapie jako Łopuszna, gdyż zarówno przewodnicy, jak i sami pasterze mieli wątpliwości, gdzie ona leży. Podobny problem pojawił się na szczycie Wysokiej, góry wznoszącej się na ponad 5700 m n.p.m., z której rozpościerały się niebotyczne, bez końca ciągnące się pasma Karpat: „Nie mieliśmy ze sobą, co uczuliśmy tu dotkliwie po tylu trudach, takiego przewodnika, który świadom miejscowości i okolic, i widoków zdołał nam wskazać, które to pomiędzy pasmami jest Czarnohorą, a gdzie są Gorgany z Chomiakiem"76. W miarę upływającego czasu coraz bardziej skarżył się Turczyński na obojętność i leniwość zatrudnionych, ich małą operatywność i energię. Wbrew przekonaniu, że górale potrafią określić i przewidzieć pogodę, ci twierdzili, że nawet blisko stanu nieba nigdy przewidzieć jej nie mogą. Gdy turyści odprawili, z przyczyn od siebie niezależnych, lepszego przewodnika, do ich dyspozycji pozostał drugi, gorszy, który najpierw zaspał, a potem upił się w karczmie. Będąc pod wpływem alkoholu, na tyle poczuł się pewny siebie, iż rozpoczął targ o zwiększenie okrojonego uposażenia, czym doprowadził towarzystwo do irytacji i podjęcia restrykcyjnych kroków. Ostatecznie, chcąc opanować konflikt, turyści zdecydowali się samodzielnie nieść swoje bagaże, udowadniając w ten sposób przewodnikowi, że staje się im zbędny. Sytuacja zakończyła się jednak polubownie:

Lazł pijanica czas jakiś za nami, po czym trochę się już wytrzeźwiawszy i widząc, że to nie żarty, zaczął obiecywać nam, że już się poprawi i słuchać nas będzie; oddaliśmy mu więc na jego prośby nazad rzeczy nasze, i odtąd niósł je, to narzekając, to znów przepraszając, aż do Sołotwiny ${ }^{77}$.

Historię tę opisał Turczyński ku przestrodze dla innych turystów, dodając, że w tej części Karpat człowiek zdany jest na przypadkowy wybór przewodników, albowiem ,tutaj [...] najmuje się takich, jacy się zdarzą, o których więc naprzód wiedzieć nie można, czy będą dobrymi, a nawet czy drogę znają tam, gdzie się prowadzić podejmą" ${ }^{78}$. Te przygody nie wpłynęły jednak negatywnie na ogólne wrażenie wyniesione z kilkudniowego pobytu w dzikich, ale malowniczych Karpatach.

Zainteresowanie górami oddalonymi jeszcze bardziej na wschód było nieporównywalnie mniejsze niż fascynacje Alpami czy Tatrami. Stosunkowo słabo poznany przez ówczesnych Polaków był Krym, chociaż tamtejsze góry kojarzyły się z osobą Adama Mickiewicza i jego sonetami. Efektem wycieczki poety na Wschód (datowanej na 1825 rok) był cykl niezwykłych pod względem treści i formy utworów, w której całkowicie złamana została dotychczasowa konwencja literacka sięgająca swoimi korzeniami XIII i XIV wieku. W Sonetach krymskich nadawał Mickiewicz egzotycznej, odmiennej kulturowo krainie zupełnie

76 Ibidem, s. 149.

77 Ibidem, s. 151.

78 Ibidem. 
nowego, oryginalnego znaczenia, przepuszczając tę poetycką wizję przez pryzmat romantycznego czucia i widzenia. W takim ujęciu góry Krymu przeistaczały się w płaszczyznę dialogu dwóch różnych kultur, przeciwstawnych światów i osobowości reprezentujących inną filozofię życia. Bohaterami tego dialogu byli: Pielgrzym — tułacz, europejski turysta, i Mirza — przewodnik, mieszkaniec Wschodu. Konfrontacja ich postaw dokonywała się w przestrzeni dla pierwszego niezwykłej, intrygującej, dla drugiego - znanej i oswojonej. Mirza wziął na siebie trud wprowadzenia $\mathrm{w}$ arkana swojego świata, wtajemniczenie $\mathrm{w}$ tajniki Wschodu ukształtowanego przez kulturę europejską, zagubionego w życiu Pielgrzyma. Jako przewodnik usiłował nie tylko pokazać mu piękno krymskich gór, ale także przez ich pryzmat — świat Orientu. Całkowita inicjacja Pielgrzyma nie była jednak możliwa, bo doświadczeń Mirzy nie udało się w pełni zwerbalizować i przełożyć na język zrozumiały przez romantycznego poetę ${ }^{79}$. Dla Europejczyka już góry Krymu były bardzo egzotyczne i frapujące, a tym bardziej te leżące w głębi Azji. Kaukaz bardzo oddalony, mało dostępny i przez to tajemniczo-groźny w opisach literackich pojawiał się niezbyt często ${ }^{80}$. Tym bardziej uwagę czytelnika przyciągała krótka relacja z wyprawy w 1873 roku zamieszczona na łamach „Pamiętnika Towarzystwa Tatrzańskiego”. Docelowym jej punktem okazał się spływający ze szczytu Kazbeku wielki lodowiec spadający ośmioma długimi ramionami w głąb doliny, którą płynęła, często wzbierająca i przez to bardzo niebezpieczna, rzeka Terek. Do zrealizowania swojego zamysłu Rehman zatrudnił jednego z najlepszych przewodników Osipa Hucinwała, a ten na wyprawę zjawił się uzbrojony w kindżał, długą strzelbę i toporek wraz z koniem i towarzyszącym wieśniakiem, którego zadaniem miało być niesienie bagaży. „Poranek był pogodny, ale ponad wyższymi dolinami przeciągały szare chmury, a przewodnik zapytany, czy można liczyć tego dnia na pogodę, spojrzał ku Kazbekowi i odrzekł z kwaśną miną: »Kak Boh das't budjet i pogoda «"81. Po górach kaukaskich podróżowano konno, to znaczy, że jechał turysta, a za nim w wolnym tempie podchodzili do góry przewodnicy. Gdy osiągnięto określoną wysokość, czyli w miejscu, w którym kończyły się łąki i zaczynała się bardziej niebezpieczna droga, pętano konia, zostawiając go pasącego się na trawie, starannie ukrywano część zbytecznego bagażu i rozpoczynano podejście. W tym momencie zauważyć należy, że prawdziwa górska eskapada dla Rehmana rozpoczynała się od wysokości równej Łomnicy. W takich okolicznościach podziw wzbudzać musiał nie tylko roztaczający się szeroki krajobraz, ale także niesamowita szata

79 Zob. C. Zgorzelski, ,, Pielgrzym w krainie dostatków i krasy”, [w:] idem, O lirykach Mickiewicza i Stowackiego, Lublin 1961; S. Makowski, Świat „, Sonetów krymskich” Adama Mickiewicza, Warszawa 1969; W. Kubacki, Z Mickiewiczem na Krymie, Warszawa 1977.

${ }^{80} \mathrm{Z}$ najnowszych publikacji o tych górach na uwagę zasługuje praca: R. Gadamska-Serafin, Góry Kaukaz w poezji i wspomnieniach Franciszka Ksawerego Pietraszkiewicza, [w:] O Kaukazu po Sudety. Studia i szkice o zamieszkiwaniu i poznawaniu gór dalekich i bliskich, red. E. Grzęda, Kraków 2020, s. 17-68.

81 A. Rehman, Kilka kartekz Kaukazu. Ustępy z dotąd nieogłoszonejpodróżyodbytej w 1873 roku przez Dr. A. Rehmana, „Pamiętnik Towarzystwa Tatrzańskiego” 1879, nr 6, s. 31. 
roślinna, na którą składały się zróżnicowane rododendrony czy alpejskie wierzby. Zdarzały się też inne niespodzianki, a jedną z nich była mała kamienna piramida, którą naukowiec uznał za znak trygonometryczny. Z błędnego myślenia wyprowadził go przewodnik, „upewniając, że to jest miejsce święte, do którego ściągają raz do roku nabożni Osetyńcy z okolicznych wiosek" ${ }^{2}$. W szczelinach między kamieniami widoczne były lampki, potłuczone flaszki, kawałki odzieży, drutu i szkła, a szczyt piramidy zwieńczało poroże należące do antylopy zwanej przez Osetyńców turem. Przewodnik zapytany o sens i znaczenie mijanego miejsca wszystkiego do końca nie zamierzał wyjaśniać, by ostatecznie zakończyć sprawę lakonicznym stwierdzeniem, że twórcy kamiennej piramidy „kozła ubili i zjedli, a głowę ofiarowali Panu Bogu"83. Botanizujący naukowiec za punkt honoru uznał zbadanie jednej z wysepek porośniętych zielenią, przyciągającej wzrok w otoczeniu białego zlodowaciałego pola. Spenetrowanie takiej oazy zieleni usytuowanej na lodowcu dawało możliwości poznania i określenia roślin tam rosnących, ich wegetacji, co zapewne w świecie florystycznym stanowiło sporą gratkę naukową. Dotarcie do owej enklawy zieleni wymagało dużego poświęcenia, ale to było wbrew logice i zdrowemu rozsądkowi, które nakazywały zachowanie bezpieczeństwa. Podjęte zadanie okazało się na tyle trudne, że pomimo zachowania ogromnej ostrożności każdy błąd człowieka mógł grozić katastrofą. W pewnym momencie nawet otarto się o tragedię. Relacjonował Rehman:

Wieśniak towarzyszący nam poślizgnął się, upadł na ziemię i znikł nagle we mgle; zjechał on przynajmniej czterdzieści kroków w dół [...], a powróciwszy do nas, oświadczył kategorycznie, że on nie „durak”, ażeby łamał kark za kwiatkami i że ani kroku dalej nie ruszy ${ }^{84}$.

W obliczu takiego ostrego protestu pomocnika zupełnie inaczej zachował się „poczciwy” Huncinwoł, który odpowiadając za bezpieczeństwo wyprawy, postanowił osobiście spenetrować dojście do wysepki. Ostatecznie jednak jego spostrzeżenia dokonane podczas tej lokalnej wizji były jednoznaczne. Należy zrezygnować z zamiaru ze względu na to, że kąt nachylenia stoku bardzo się w tym miejscu zwiększa i grozić to może niekontrolowanym poślizgiem. Rehman posłusznie dostosował się do zaleceń przewodnika, uznając w ten sposób jego doświadczenie i pragmatyczne podejście do górskiej przestrzeni: „Usłuchałem zdrowej jego rady i zaniechałem dalszego pochodu, a strzegąc silnie śladów zostawionych przez nasze obuwie na lodzie, dostaliśmy się do miejsca, gdzie były ukryte nasze rzeczy" 85 .

Obraz przewodnika turystycznego wyłaniający się z ogromnej ilościowo literatury podróżniczej XIX wieku jest bardzo zróżnicowany, ale jednocześnie ogromnie interesujący. Przewodnicy niemający najczęściej teoretycznego przygotowania do wypełniania swoich obowiązków w miarę upływu czasu zdobywają coraz większe kwalifikacje i sprawności, które ułatwiają im dotarcie w takie

82 Ibidem, s. 33.

83 Ibidem.

${ }^{84}$ Ibidem, s. 34.

85 Ibidem. 
miejsca, o jakich marzy turysta. Wyprawy te, stając się też bardziej bezpieczne, znacznie przyspieszają rozwój turystyki. Dzięki pomocy przewodników ludzie żyjący w XIX wieku mogą penetrować nieomal wszystkie góry Europy. Wyjątkowo dobrze na tym tle prezentują się przewodnicy tatrzańscy, których literacki wizerunek będzie przedmiotem dalszych badań.

\section{Bibliografia}

Adams J.Q., Listy o Śląsku, wstęp W. Dynak, Wrocław 1992.

A.K., Utamek podróży po Szwajcarii, „Przyjaciel Ludu” 1839, nr 36.

Budzyński W., Niemcy i Szwajcaria, t. 1-2, Wilno 1856.

Choroszy J.A., Huculszczyzna w literaturze polskiej, Wrocław 1991.

Chwaściński B., Mont Blanc. Zdobycie szczytu, „Wierchy” 32, 1983, s. 86-118.

Dobrzycka A., Atanazy Raczyński w Alpach, „Wierchy. Rocznik Poświęconym Górom” 56, 1987, s. $65-85$.

Dziędzielewicz J., Wycieczki po wschodnich Karpatach, „Pamiętnik Towarzystwa Tatrzańskiego” 2, 1877, s. 2-38.

Gadamska-Serafin R., Góry Kaukaz w poezji $i$ wspomnieniach Franciszka Ksawerego Pietraszkiewicza, [w:] Od Kaukazu po Sudety. Studia i szkice o zamieszkiwaniu i poznawaniu gór dalekich i bliskich, red. E. Grzęda, Kraków 2020, s. 17-68.

Hankiewicz W., Wycieczka na Czarnohorę, „Pamiętnik Towarzystwa Tatrzańskiego” 1879, nr 4, s. 37-46.

Kincel R., Początki przewodnictwa turystycznego w Karkonoszach, Jelenia Góra 1972.

Kolbuszewska E., Romantyczne przeżywanie przyrody. Znaczenie wartości, style zachowań, Wroclaw 2007.

Kolbuszewska E., Szczyt górski jako miejsce transgresji. Wersja romantyczna, „Góry - Literatura - Kultura" 2017, nr 11, s. 57-68.

Kolbuszewski J., Górskie przewodniki (Uwagi o współczesności i tradycji gatunku), [w:] idem, Góry. Przestrzenie i krajobrazy, Kraków 2020, s. 25-40.

Koziebrodzki W., Pierwszy rocznik Klubu Alpejskiego Francuskiego, „Pamiętnik Towarzystwa Tatrzańskiego" 1, 1876, s. 87-93.

Koźmian S.E., Podróż nad Renem i w Szwajcarii (w 1846 roku odbyte), Poznań 1877.

Kraszewski J.I., Kartki z podróży 1858-1864, t. 2, oprac. P. Hertz, Warszawa 1977.

Kraszewski J.I., Wspomnienia Odessy, Jedyssanu i Dudżaku, Warszawa 1985.

Kubacki W., Z Mickiewiczem na Krymie, Warszawa 1977.

Makowski S., Świat „, Sonetów krymskich” Adama Mickiewicza, Warszawa 1969.

Malczewski A., Podróż na górę biała (Mont-Blanc), opisana w liście do profesora Picteta, „Dziennik Wileński” 1818, nr 11, s. 486-493.

Mączak A., Peregrynacje. Wojaże. Turystyka, Warszawa 1984.

Morawski J., Podróż w Śląsku w roku 1815 opisana w listach do brata, [w:] Polskie podróże po Śląsku w XVIII i XIX wieku (do 1863), oprac. A. Zieliński, Wrocław 1974, s. 94-103.

Najnowsza podróż na górę Mont Blanc, „Przyjaciel Ludu” 1838, nr 42.

Nakwaska A., Wspomnienie krótkiej podróży 1844 roku, [w:] Polskie podróże po Ślasku w XVIII i XIX wieku (do 1863), oprac. A. Zieliński, Wrocław 1974, s. 192-200.

Nakwaska A., Wspomnienie podróży odbytej roku 1837, „Przyjaciel Ludu” 1838, nr 5.

Padalica T. [Fisz Z.], Listy z podróży, t. 3, Wilno 1859.

Przychodniak Z., Dwie wiadomości o Antonim Malczewskim w prasie Warszawskiej z 1826 i 1837 ro$k u$, „Pamiętnik Literacki” 76, 1985, nr 2, s. 257-265. 
Rehman A., Kilka kartek z Kaukazu. Ustępy z dotąd nieogłoszonej podróży odbytej $w 1873$ roku przez Dr. A. Rehmana, „Pamiętnik Towarzystwa Tatrzańskiego” 1879, nr 6, s. 1-32.

Saulsonowa R., Warmbrunn i okolice jego w 38 obrazach zebranych w 12 wycieczkach przez Pielgrzymke w Sudetach, oprac. P. Cimicki, Wrocław 2004.

Stownik 100 tysięcy potrzebnych stów, red. J. Bralczyk, Warszawa 2006.

Staffa M., Karkonosze, Wrocław 1996.

Stęczyński B.Z., Sudety jako dalszy ciąg poematu Tatry, oprac. J. Kolbuszewski, Jelenia Góra 1981.

Stęczyński B.Z., Śląsk. Podróż malownicza w 25ciu pieśniach [rękopis w zbiorach ZNiO we Wrocławiu sygn. 3424/1, 1850].

Sudolski Z., Polski list romantyczny, Kraków 1997.

Turczyński E., Wycieczka na Sywulę i Wysoka, „Pamiętnik Towarzystwa Tatrzańskiego” 1883, nr 8, s. 124-137.

Wajgiel L., O Burkucie i jeziorach czarnohorskich (opis wycieczki odbytej w 1879), „Pamiętnik Towarzystwa Tatrzańskiego" 1880, nr 5, s. 60-71.

Zapałowicz H., Z Czarnohory do Alp Rodneńskich, „Pamiętnik Towarzystwa Tatrzańskiego” 1881, nr 6, s. 74-85.

Zgorzelski C., O lirykach Mickiewicza i Stowackiego, Lublin 1961. 